\title{
Range 8C Rehabilitation Demonstration Project, Hohenfels Training Area, Germany: Final Report
}

by S.D. Zellmer, R.R. Hinchman, D.O. Johnson, W.D. Severinghaus, " and I.J. Brent*

Reclamation Engineering and Geosciences Section, Energy Systems Division, Argonne National Laboratory, 9700 South Cass Avenue, Argonne, Illinois 60439

November 1991

Work sponsored by United States Army Corps of Engineers, Construction Engineering Research Laboratories, Environmental Division, Champaign, Illinois

"Severinghaus is affiliated with U.S. Army Corps of Engineers, Construction Engineering Research Laboratories, Environmental Division, and Brent with Environmental Management Office, Directorate of Engineering and Housing, Headquarters, 282nd Base Support Battalion, Hohenfels, U.S. Army. 


\section{Contents}

Acknowledgments.... ........................................................ v

Abstract..........................................................................

1 Introduction................................................................. 1

2 Background.................................................................. 3

2.1 Hohenfels Training Area .................................................... 4

2.2 Range 8C.................................................................. 6

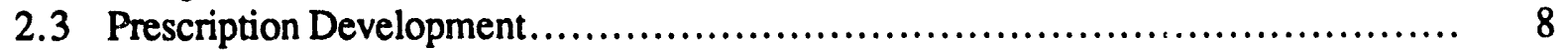

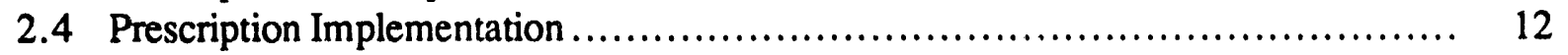

3 Goal, Objectives, and Approach ............................................ 13

4 Methods...................................................................... 15

4.1 Vegetation Studies ......................................................... 15

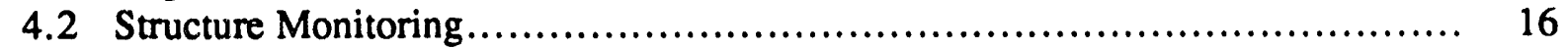

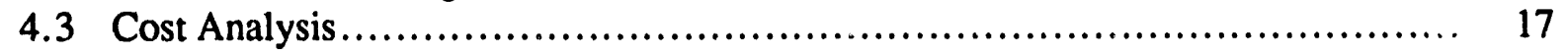

5 Results and Discussion ..................................................... 18

5.1 Vegetation Studies ......................................................... 18

5.2 Structure Monitoring.................................................... 27

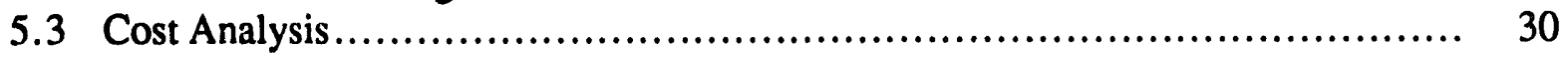

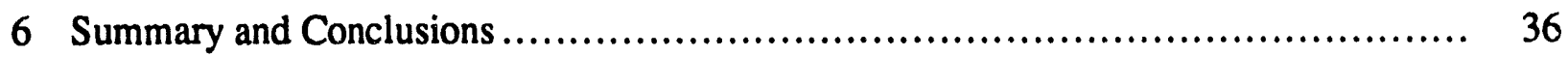

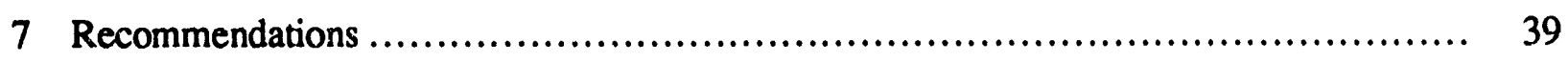

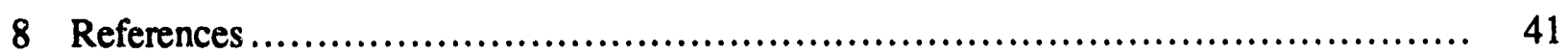

\section{Figures}

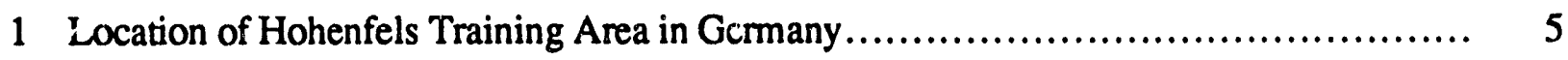

2 Location of the Project Site at Hohenfels Training Area $\ldots \ldots \ldots \ldots \ldots \ldots \ldots \ldots \ldots \ldots \ldots \ldots$

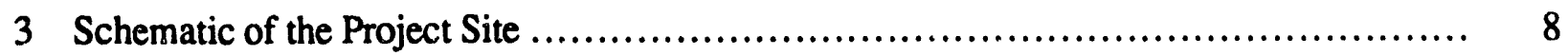




\section{Figures (Cont.)}

4 Appearance of Riprap Waterbars after Installation across a Waterway Channel at the Project Site

5 Collection of Ground Cover Data by the Point-Intercept Method Using the PointFrame at the Project Site

\section{Tables}

1 Mean Percent Cover for Each Category by Prescription, Soil Condition, and

Collection Date

2 Average Cost per Unit of Prescriptions Used at the Range 8C Site

3 Average Cost per Unit of Materials Used during the Rehabilitation of the

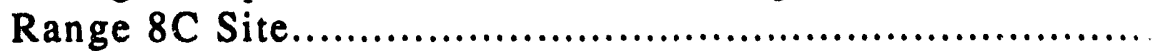

4 Average Cost per Unit for Labor and Equipment Used during the Rehabilitation of the Range 8C Site 


\section{Acknowledgments}

The monitoring effort at the Range $8 \mathrm{C}$ Rehabilitation Demonstration Project site at Hohenfels Training Area (HTA) in Germany was possible only because of the contributions and cooperation of a number of individuals and organizations. Colonel Gunther Seibert, Commander of HTA, personally supported the Range $8 \mathrm{C}$ effort, and several new environmental awareness and improvement programs were initiated at HTA under his command. Special thanks and recognition are extended to him and his staff.

Major Edward Tucker and his staff at the Directorate of Engineering and Housing (DEH), HTA, provided support on numerous occasions. Members of the Environmental Management Office of DEH rendered valuable assistance throughout the monitoring effort. Their day-to-day support and services are greatly appreciated.

The U.S. Army Corps of Engineers Construction Engineering Research Laboratories (USACERL) is gratefully acknow/ledged for providing the necessary funding for both the implementation and monitoring phases of the project.

Finally, special thanks and appreciation are extended to Barbara Sullivan for her assistance and patience throughout the entire project. 


\title{
Range 8C Rehabilitation Demonstration Project, Hohenfels Training Area, Germany: Final Report
}

\author{
by \\ S.D. Zellmer, R.R. Hinchman, D.O. Johnson, \\ W.D. Severinghaus, and J.J. Brent
}

\begin{abstract}
More than 30 years of intensive and continual tactical training has caused extensive environmental damage at the U.S. Army Hohenfels Training Area in Germany. The Range 8C Rehabilitation Demonstration Project, followed by a three-year monitoring effort, was conducted to develop and evaluate the environmental and economic effectiveness of seven revegetation and four erosion control prescriptions implemented at a 16 -ha site. The point-intercept method was used to measure the types and amounts of vegetation established and the changes in the vegetative community during three years of military use on the seven areas treated with revegetation prescriptions. Field observations were made to determine the suitability and durability of four types of erosion control structures. Soil fertility and a source of seed appeared to be the most limiting factors in establishing vegetation, while seedbed preparation had only a minor influence. Grasses appeared to be more resistant to vehicle traffic than did other types of vegetation. Because grassed waterways were used as roads by military vehicles and a system of graded terraces was expensive, these erosion control prescriptions were unsuitable and uneconomical for use on training areas. Low-cost riprap waterbars anci porous check dams slowed the velocity of runoff, trapped sediments, and were durable. Recommendations were formulated to improve the environmental and economic effectiveness of future rehabilitation efforts on tactical training areas.
\end{abstract}

\section{Introduction}

Approximately one-third of the U.S. Army is deployed in Europe, but only about 87,900 ha $(217,200$ acre) of land is available in Europe for housing and training Army personnel. For comparison, the available training area in Europe is approximately equal to that of Fort Hood, Texas. The majority of U.S. Army Europe (USAREUR) units are stationed in Germany, and they must maintain tactical combat readiness because of their strategic location. Tactical training in the densely populated and highly industrialized German countryside is expensive, primarily because compensation for damage attributable to tactical training maneuvers is high and the costs increase each year. The number and sizes of existing tactical training areas are limited because of the 
intensive land use in Germany. New and improved weapon systems have changed tactical training doctrines; they now require combat units to operate over larger sectors of the landscape and engage targets at greater ranges than in the past. Also, United States tactical training areas are often used by combat units of other counuries in the North Atlantic Treaty Organization. These factors place U.S. training areas in Germany under high training pressure because a large number of combat units use an area during a given period. As a result of the overuse and abuse of existing training areas, the vegetative ground cover has been damaged and destroyed at many of those areas. With the loss of plant cover, the rate of soil erosion accelerates, and soil erosion adversely affects environmental quality, creates safety hazards, and diminishes training realism.

The most cost-effective method of stabilizing soil and controlling erosion is to establish and maintain a self-sustaining vegetative ground cover because plant cover stabilizes the soil surface, traps sediments, and slows the velocity of runoff. Structures designed to control erosion (such as porous check dams and rock waterbars) also trap sediments and reduce the velocity of runoff, thereby preventing the development of gullies, which are major safety hazards in training areas. A barren field does not resemble the typical landscape and is not a realistic habitat for military training activities. The areas beyond the borders of training areas benefit from plant cover and erosion control because the amount of sediment in runoff is reduced and the quality of the water in receiving streams is not degraded. Lower velocities and volumes of runoff also diminish the potential for flooding in adjacent streams and flood plains. Moreover, the appearance of a barren and eroded landscape at training areas leads to public concerns about the existence of the installations. By establishing and maintaining vegetative ground cover, a training area rehabilitation and maintenance program can cost-effectively provide combat units with an environmentally sound, safe, and realistic training habitat and alleviate public concerns about the presence of training areas. 


\section{Background}

The Environmental Division of the U.S. Army Corps of Engineers Construction Engineering Research Laboratories (USACERL), located in Chainpaign, Illinois, has been given the responsibility of developing and implementing the Integrated Training Area Management (ITAM) program. The ITAM program is a systematic program for land management that is designed to ciemonstrate the processes and tools necessary to enhance resource conservation and training missions at U.S. Army installations. The major thrusts of the ITAM program are as follows: (1) development of a standardized method for assessing environmental conditions and land-use capabilities, (2) integration of training needs with the training mission and environmental concerns, (3) development of programs to educate military personnel about environmental awareness and resource conservation, (4) development of a computer-based, land-managementdecision and scheduling system for the analysis of resource data, and (5) development of costeffective rehabilitation and maintenance technologies for training areas.

The initial ITAM effort in Europe was started in late 1985 at the Hohenfels Training Area (HTA), located in Germany. The Reclamation Engineering and Geosciences (RE\&G) Section of the Energy Systems Division at Argonne National Laboratory (ANL) was requested by USACERL to assist in the development of a rehabilitation demonstration project (element 5 of the ITAM program). Because the section has more than 15 years of experience in applied land reclamation research and is successfully implementing a similar USACERL/ANL training range rehabilitation demonstration project at Fort Carson, Colorado, the RE\&G Section at ANL was selected to undertake the rehabilitation project in Germany. The Range 8C Rehabilitation iemonstration Project - the initial range rehabilitation effort in the ITAM program in West Germany - involved the development, implementation, and evaluation of rehabilitation prescriptions for a typical tactical training range at HTA.

The goal of the Range 8C Rehabilitation Demonstration Project was to develop and demonstrate ecologically effective and economically feasible methods for revegetation and erosion control that could be used to provide a stable, safe, and realistic environment for tactical training. To accomplish this goal, the following tasks were undertaken:

- Selection of a demonstration site with environmental conditions and training damage resembling those of HTA,

- Collection of information on the costs and availability of rehabilitation materials and equipment in West Germany,

- Assessment of the prerehabilitation conditions of the demonstration site,

- Desigrı of rehabilitation prescriptions for various site-specific conditions to improve the environmental quality of the dernonstration site, 
- Implementation of the rehabilitation prescriptions with the assistance of a local contractor,

- Evaluation of the environmental effectiveness and cost of each rehabilitation prescription with renewed tactical training at the demonstration site, and

- Transfer of the information gained from the rehabilitation demonstration project to personnel responsible for future rehabilitation efforts at HTA.

The initial effort on the Range $8 \mathrm{C}$ Rehabilitation Demonstration Projest began in January 1986 with an inspection trip of HTA, during which ANL staff surveyed HTA to assess training damage, identify the types of vegetation present, determine the degree of soil erosion, and determine the topography of the area. Members of ANL staff held meetings with representatives of USACERL, the U.S. Seventh Army Training Command (7ATC), HTA, and German governmental organizations to discuss concerns about and potential solutions to training area rehabilitation problems. During the inspection trip, ANL staff collected background information on the climate of HTA, as well as information on the reclaniation materials and equipment available in the area. After the initial inspection trip, ANL staff provided the Directorate of Engineering and Housing (DEH) at HTA with the selection criteria for a suitable demonstration site. The DEH staff located a number of candidate demonstration sites, and during a second visit to HTA in April 1986, ANL staff selected Range $8 \mathrm{C}$ as the site for the rehabilitation demonstration project.

\subsection{Hohenfels Training Area}

Hohenfels Training Area is the U.S. Army Combat Maneuver Training Center in Europe and is operated by the 7ATC headquarters in Grafenwöhr, West Germany. Hohenfels Training Area is located amid the forest and farmland in the Oberpfalz region of Bavaria, approximately $120 \mathrm{~km}(75 \mathrm{mi})$ north of Munich and about halfway between Nuremberg and Regensburg (Figure 1). In 1938, the German Armed Forces (Wehrmacht) established HTA as a military area for training German forces and testing weapons systems. During World War II, HTA was used as a prisoner of war camp. The American Army occupied HTA in April 1945, and parts of the original installation were used as a displaced-person camp until 1949 (Griesbach 1988). In 1951, the U.S. Army requisitioned HTA for use as a tactical training area and enlarged it to its current area of about 16,200 ha $(40,000$ acre) in 1952 . The HTA is currently the largest maneuver training area available to the U.S. Army in Europe.

The HTA and Oberpfalz regions of Bavaria have a humid mesothermal climate. Winters are moderately cold; January temperatures average about $0^{\circ} \mathrm{C}\left(32^{\circ} \mathrm{F}\right)$, but the temperature may fall to $-25^{\circ} \mathrm{C}\left(-13^{\circ}\right)$ for a few days. Summers have warm days and cool nights, and temperatures average $13^{\circ} \mathrm{C}\left(55^{\circ} \mathrm{F}\right)$ during July, the warmest month. Precipitation, mainly rain, is fairly evenly distributed throughout the year and averages about $960 \mathrm{~mm}$ (37.8 in.). Snowfall can occur from 


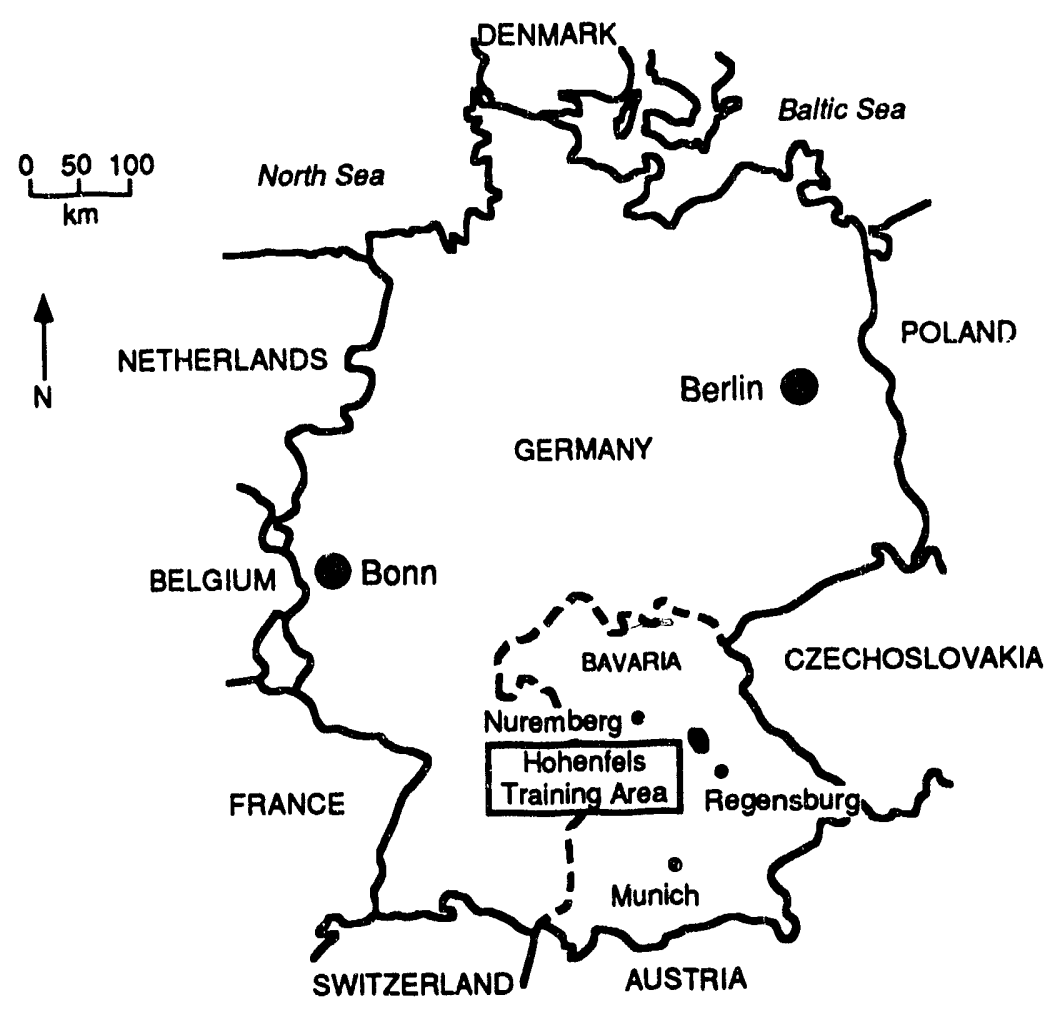

FIGURE 1 Location of Hohenfels Training Area in Germany

late October through early April. During the winter, soils are not normally frozen, and snow cover is limited to a few days because daytime temperatures are above freezing.

Hohenfels Training Area is slightly higher in elevation than the adjacent landscape, with elevations ranging from about $650 \mathrm{~m}(2,050 \mathrm{ft})$ at the highest hiliop near the western botindary to approximately $350 \mathrm{~m}(1,150 \mathrm{ft})$ at the lowest point in the southeastern corner. The pirysiography of the training area is rolling hills alternating with wide, concave valleys. Valley floors usually have moderate slopes of less than $10 \%$ and are less than $100 \mathrm{~m}(328 \mathrm{ft})$ below the adjacent ridge tops. Upper slopes near the ridge tops are often very steep, with slopes of more than $45 \%$, while the lower slopes adjacent to the valley floors are moderately steep to steep, ranging from 10 to $30 \%$. The geology and native soils with vegetative cover at HTA have moderate to high infiltration rates. Only two perennial streams originate in HTA, the Kesselgraben in the southeastern corner and the Forellenbach starting near the cantonment area. During periods of rainfall or snow melt, intermittent streams also flow in most valleys. Because HTA is at a slightly higher elevation than the surrounding countryside, all drainage flows off HTA and into three rivers that are the general boundaries on three sides of HTA - the Lauterach on the north, the Vils on the east, and the Forellenbach on the southeast.

The area surrounding HTA is about equally divided between forest and farmland. Valleys and gentle side slopes are in meadows harvested for forage or used for the production of small 
grains, rape, and corn for forage. The steeper slopes and many ridge tops are in coniferous and mixed forest. The land use of HTA, before it was converted to a training area, was similar to that of the adjacent countryside (Griesbach 1988), and the steeper slopes and ridge tops have remained in coniferous forests and mixed forests that are managed by the German Federal Forest Service. Meadows have remained open areas because of training activities and a sheep grazing program. Fields that were cultivated have reverted to abandoned field communities of grasses and legumes adapted to the region. Although these plant communities contain grass and legume species adapted to the local soils and climate, many large areas are barren and disturbed, lacking adequate plant cover to control erosion and runoff.

For almost 40 years, HTA has been used by the U.S. Army for tactical training that requires tanks, armored personnel carriers, and support vehicles to be deployed throughout the training area. Continued military traffic in the valleys and on their side slopes has produced numerous trails and areas devoid of vegetation that are subject to accelerated erosion. The tactical concealment of vehicles has destroyed virtually all of the ground cover along the forest edge. Because of the loss of vegetation for concealment, vehicles maneuvering for attack or defense positions are now forced to use the forested areas, a practice that damages trees and destroys the forest understory. The construction of tank ditches and defilade positions damages or destroys vegetative ground cover and therefore exposes the soil, which increases the erosion rate. At strategic locations on the landscape, the soil is disturbed so often that natural revegetation does not occur and soil erosion :s rampant in these areas. As a result, the landscape has lost all semblance of the adjacent countryside and lacks training realism. Because erosion and runoff are uncontrolled, gullies have developed, creating safety hazards for troops and equipment. Sediments are carried by runoff to receiving streams outside HTA. Local residents find the degradation of water quality in streams adjacent to HTA and the disheveled appearance of the landscape offensive, and these problems are of serious concern to U.S. Army representatives.

\subsection{Range 8C}

Range $8 \mathrm{C}$ was selected as the site of the rehabilitation demonstration project during the HTA inspection trip in April 1986. The site is within a watershed adjacent to the north boundary of HTA, about $1 \mathrm{~km}(0.6 \mathrm{mi})$ southeast of the village of Hohenburg on the banks of the Lauterach River (Figure 2). The northern boundary of the site is the North Tank Road, and parallel forestcovered ridges are the eastern and western boundaries of the watershed. The valley between the ridges leads to a broad upland meadow that extends through saddles at the southeast and southwest corners of the watershed. A large forested hill is the southern boundary of the watershed. The watershed covers about 62 ha (153 acres), of which about 5 ha (12 acres) is open valley, 16 ha (40 acres) is upland meadow, and the remaining 41 ha (101 acres) is forest on the ridges and steep slopes (Figure 3). All drainage from the watershed is concentrated in a single, well-defined channel in the valley floor, which is about $5 \mathrm{~m}(16 \mathrm{ft})$ deep and $25 \mathrm{~m}(82 \mathrm{ft})$ wide at the north boundary of site. Runoff from the site passes under the North Tank Road, through the forested buffer zone on the outer edge of HTA, and into the Lauterach River about $0.5 \mathrm{~km}$ downstream from the village of Hohenburg. Main access to Range $8 \mathrm{C}$ from the North Tank Road is affurded by an unimproved tank trail that is parallel to and on the east side of the drainage channel. Before 


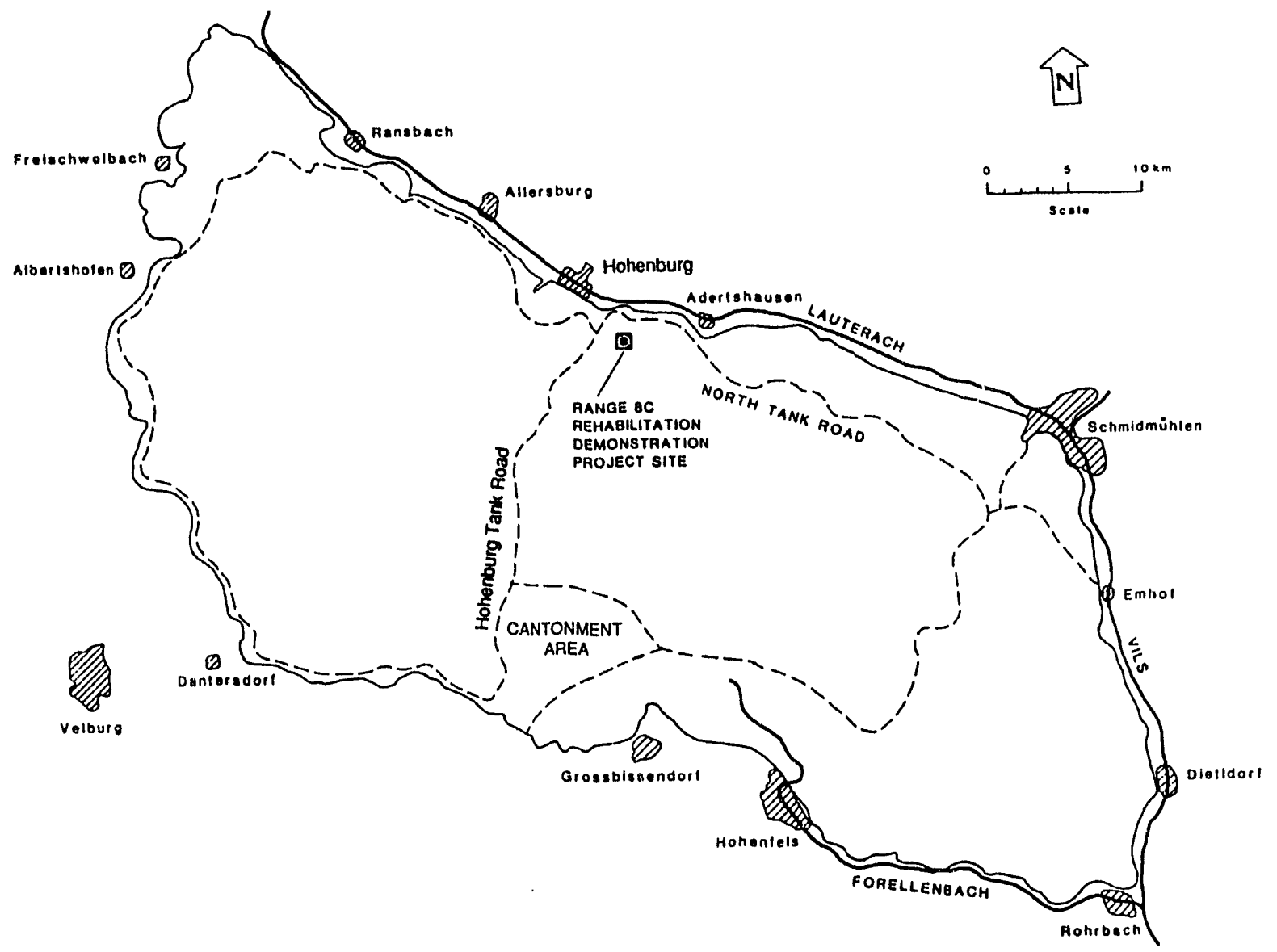

FIGURE 2 Location of the Project Site at Hohenfels Training Area

Range 8C was used as a training area (starting in the late 1930s), the upland meadow of the site was probably used as pasture or for the production of cultivated crops. Berms made of rocks (probably removed from the farm fields) delineated old field boundaries. Some sections of the berms were almost like terraces, with trees and shrubs typical of the field boundaries found on the farmiand adjacent to HTA.

Current and past military use of the site was very evident. A number of compacted, barren tank trails crossed the upland meadow; accelerated erosion occurred on the trails that ran perpendicular to the slopes and where the trails crossed the old field boundaries. Old tank ditches also ran parallel with the slope and had become channels for runoff. Some of the old tank ditches had developed in o gullies as deep as $1 \mathrm{~m}(3.3 \mathrm{ft})$ or more. Several 0.25 -ha (0.6-acre) areas had disturbed soil and were devoid of all ground cover because of extensive traffic. An area as wide as $15 \mathrm{~m}$ (49.2 ft) along the forest edge was barren, compacted, and rutted from vehicle traffic. Sheet and rill erosion was evident in both the upland meadow and forest where the ground cover had been damaged or destroyed by moving vehicles and training activities. Vehicles had also moved into the forest, and the trails that were created by these vehicles ran both perpendicular to 


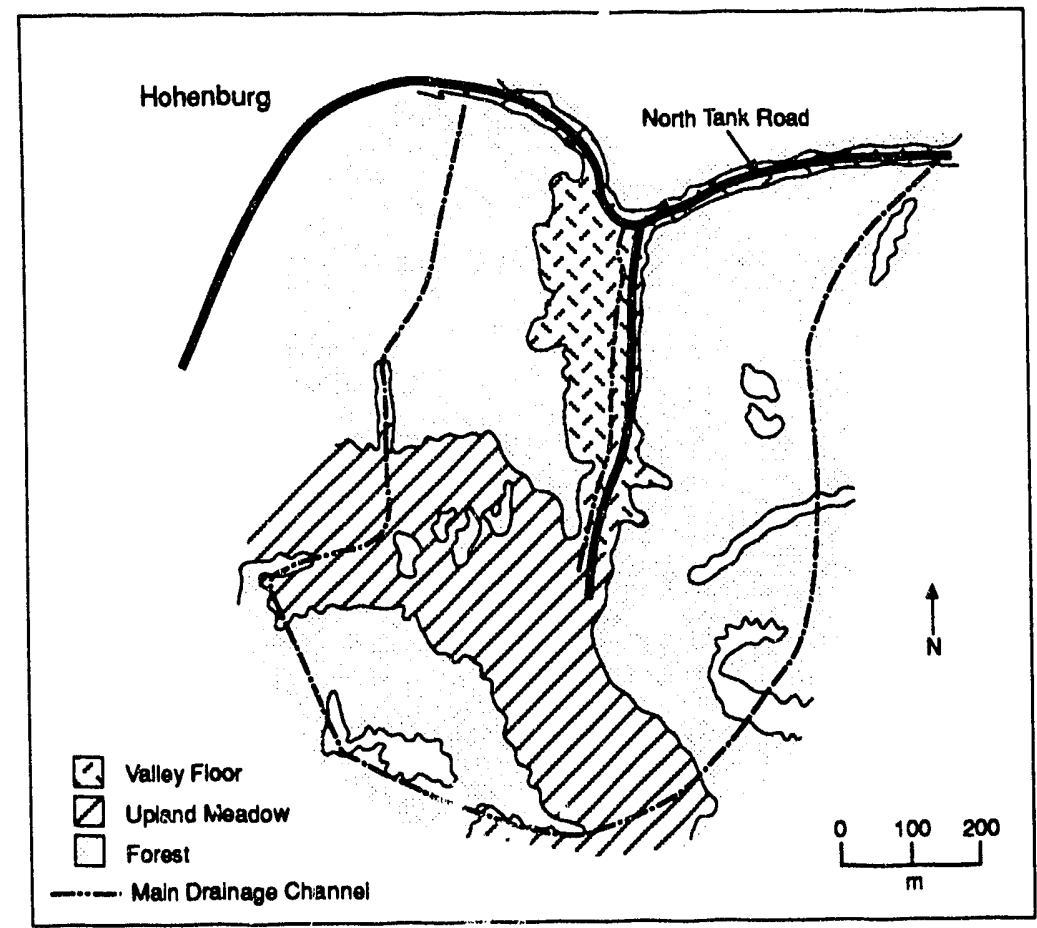

FIGURE 3 Schematic of the Project Site

the slopes and parallel to the forest edge. Because the west ridge top was used as a bivouac and refueling site, the forest understory and ground cover near the west ridge top had been damaged. The valley floor had a thick stand of grass, and banks of the runoff channel were vegetated with trees, shrubs, and grass. The main ancess road through the valley was in very poor condition. At several locations, deep swales had developed in the trail because of the unstable surface. Runoff collected in the swales, producing large mud holes across the trail. Traffic deepened and increased the sizes of the mud holes until the trail became impassable, even in dry weather.

\subsection{Prescription Development}

A detailed inventory of site-specific conditions was made of the Range $8 \mathrm{C}$ demonstration site during April 1986. Information from the site inventory was recorded on a 1:5,000-scale topographical map of the site. The site was divided into forested and meadow areas and then subdivided by slope class, the relative amount of ground cover, and surface soil conditions. Slopes were divided into two general categories - areas with slopes of less than $12 \%$ grade and areas with slopes of more than $12 \%$ grade. Ground cover was divided into three categories more than $80 \%, 50-80 \%$, and less than $50 \%$ coverage. The surface soils were categorized as follows: soils from forested areas; soils in the meadow; unaffected, trafficked, rutted, and compacted soils; and stony soils or soil with exposed bedrock. Composite soil samples were collected from areas representing the different soil conditions and ground cover and submitted to a local university for analyses of fertility. The locations of gullies and areas of sheet and rill erosion 
were noted on the site map. Information from the detailed site inventory provided a mosaic of the soil properties, existing vegetation conditions, and landscape features of the site.

Information from the detailed site inventory was combined with various reclamation opticns (i.e., locally available reclamation materials and operations) to develop individual rehabilitation prescriptions. Eleven rehabilitation procedures or prescriptions were developed for the Range $8 \mathrm{C}$ site. Each prescription consisted of various combinations of fertilizer, seedbed preparation operations, seed mixtures, and/or erosion control structures that were matched to the types and amounts of vegetation, soil conditions, degree of erosion and topography of discrete areas at Range $8 \mathrm{C}$.

Prescription 1 consisted of an application of fertilizer. Resul $s$ of the soil analyses indicated that soils in several areas of the site were low in nitrogen, phosphurus, and potassium. On areas with more than $80 \%$ ground cover, $\mathrm{N}, \mathrm{P}_{2} \mathrm{O}_{5}$, and $\mathrm{K}_{2} \mathrm{O}$ nutrient were each broadcast at a rate of $55 \mathrm{~kg} \mathrm{ha}^{-i}\left(49.1 \mathrm{lb} \mathrm{acie}^{-1}\right)$. Plant nutrients were also broadcast at this rate on all areas that were seeded.

Prescriptions 2 and 3 combined an application of fertilizer with seeding. These two prescriptions were applied in areas with 50-80\% ground cover, and the difference between the two prescriptions was the seed mixture and planting method. Before seeding, fertilizer was broadcast at the rate described for prescription 1 (for both prescriptions). The species selected for the mixtures were adapted to the region's climatic and the site's soil conditions and were locally available at reasonable cost. All species in both seed mixtures were approved by local and Bavarian government representatives. The seed mixture used in the forested area consisted of five species of shade-tolerant grasses and two species of legumes broadcast at a rate of $42 \mathrm{~kg} \mathrm{ha}^{-1}$ ( 37.5 $\left.\mathrm{lb}_{\mathrm{acre}}{ }^{-1}\right)$. Forested areas were broadcast seeded to provide coverage between and around trees and to prevent damage to tree roots. The mixture used in the meadow was drilled at a rate of $62 \mathrm{~kg} \mathrm{ha}^{-1}$ (55.4 lb acre-1) and was made up of five species of grasses, two species of legumes, and cereal rye. The rye was added to the mixture to provide quick ground cover for immediate erosion control. Prescription 3 was also used on gently sloping ( $<12 \%$ slopes) meadow areas with less than $50 \%$ ground cover that had large rocks near the soil surface or exposed bedrock. Both seeding rates are about one and one-half to two times the normal agricultural seeding rate because experience has indicated that it is more economical to seed at a higher rate to establish a good stand than it is to reseed areas with poor stands at a later date.

Prescription 4 incorporated fertilization, seedbed preparation, and drill seeding with the meadow seed mixture and was applied to meadow areas with less than $50 \%$ ground cover. Fertilizer was applied before seedbed preparation by using the method and rate described for prescription 1. Seedbed preparation was accomplished with a 200-hp, four-wheel-drive tractor with a three-point-mounted, 3-m- (10-ft-) wide rototiller equipped with rubber tires to control the operating depth. This equipment could operate in soils with small stones. The rototiller could also be raised to skip over areas with stones on the soil surface or areas with exposed bedrock. A clodfree seedbed about $15 \mathrm{~cm}$ (6 in.) deep was prepared. After seedbed preparation, the meadow seed mixture was drilled at the rate described for prescription 3. 
Prescription 5 consisted of leveling and ripping compacted and rutted areas before

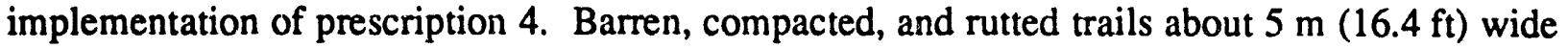
and a strip up to $15 \mathrm{~m}(49.2 \mathrm{ft})$ wide, adjacent to the forest edge, had developed in the meadow as a result of tank and other military vehicle tratfic. These compacted and rutted areas with less than $12 \%$ slope were leveled and ripped prior to fertilization, seedbed preparation, and drill seeding (prescription 4). A bulldozer equipped with a 3-m- $(9.8-\mathrm{ft}-$ ) wide front-mounted blade $\mathrm{d}$ rearmounted ripping bar was used for the leveling and ripping operations. The ripping bar had three 60-cm (24-in.) teeth spaced on 45-cm (18-in.) centers.

Prescriptions 6 and 7 were similar, except for the seed mixture used. At several locations in both the meadow and the forest, vehicle trails ran perpendicular to steep slopes ( $1 \%)$. Erosion had exposed the bedrock at several locations on some of these trails. To prevent addisonal erosion that could be caused by disturbances of the soil on the steeper slopes, the trails were hydroseed d. Fertilizer was applied at the rate specified for prescription 1, and a soil stabilizer was included in the hydroseeding mixture. Prescription 6 included the forest seed mixture (prescription 2), and prescription 7 included the meadow seed mixture (prescription 3).

Prescription 8 involved the construction of a system of graded terraces in the meadow. Terraces were used because the objectives were to reduce slope lengths, slow runoff, and trap sediments in the terrace channel. The design of a broad-base gradec terrace used on agricultural land (Beasley 1972) was modified to increase the height of the terrace ridge so that additional freeboard could be provided. The terrace system was constructed by using the bulldozer with the front-mounted blade (prescription 5). Areas disturbed by terrace construction were treated with prescription 4 after the grading operation.

Prescription 9 consisted of the construction of a grassed waterway system with riprap waterbars in the waterway channels. Several old, unfilled tank ditches ran perpendicular to the slopes in the meadow and had developed into deep gullies, which needed to be filled to minimize the safety hazards at the site. In addition, outlets were needed for the graded terraces. The waterway system with waterbars was designed to reduce the velocity of runoff and prevent the redevelopment of gullies. A flat-bottom (trapezoidal channel) waterway design was used with a minimum width of $5 \mathrm{~m}(16.4 \mathrm{ft})$, depth of $0.3 \mathrm{~m}$ (1 ft), and ratio of $4: 1$ side slopes (Beasley 1972). The channel width was increased below the terrace outlets to accommodate a higher volume of runoff (Lee ei al. 1985). The gullies were filled and the waterways were constructed by using the bulldozer : ith the front-mounted blade (prescription 5 ). The disturbed areas were treated after the grading operation with prescription 4 . Waterbars were installed below the terrace outlets, in steeply sloped sections of the waterways, and at the intersections of waterways. Waterbar construction was accomplished by dumping riprap into the waterway channel and placing the riprap into the specified configuration by using a backhoe equipped with a wide bucket. Riprap waterbars consisted of a berm of riprap perpendicular to the waterway channel. The waterbars were about $15 \mathrm{~cm}(6 \mathrm{in}$.$) high and 1 \mathrm{~m}(3.3 \mathrm{ft})$ wide, and they extended up the side slopes (Figure 4). 


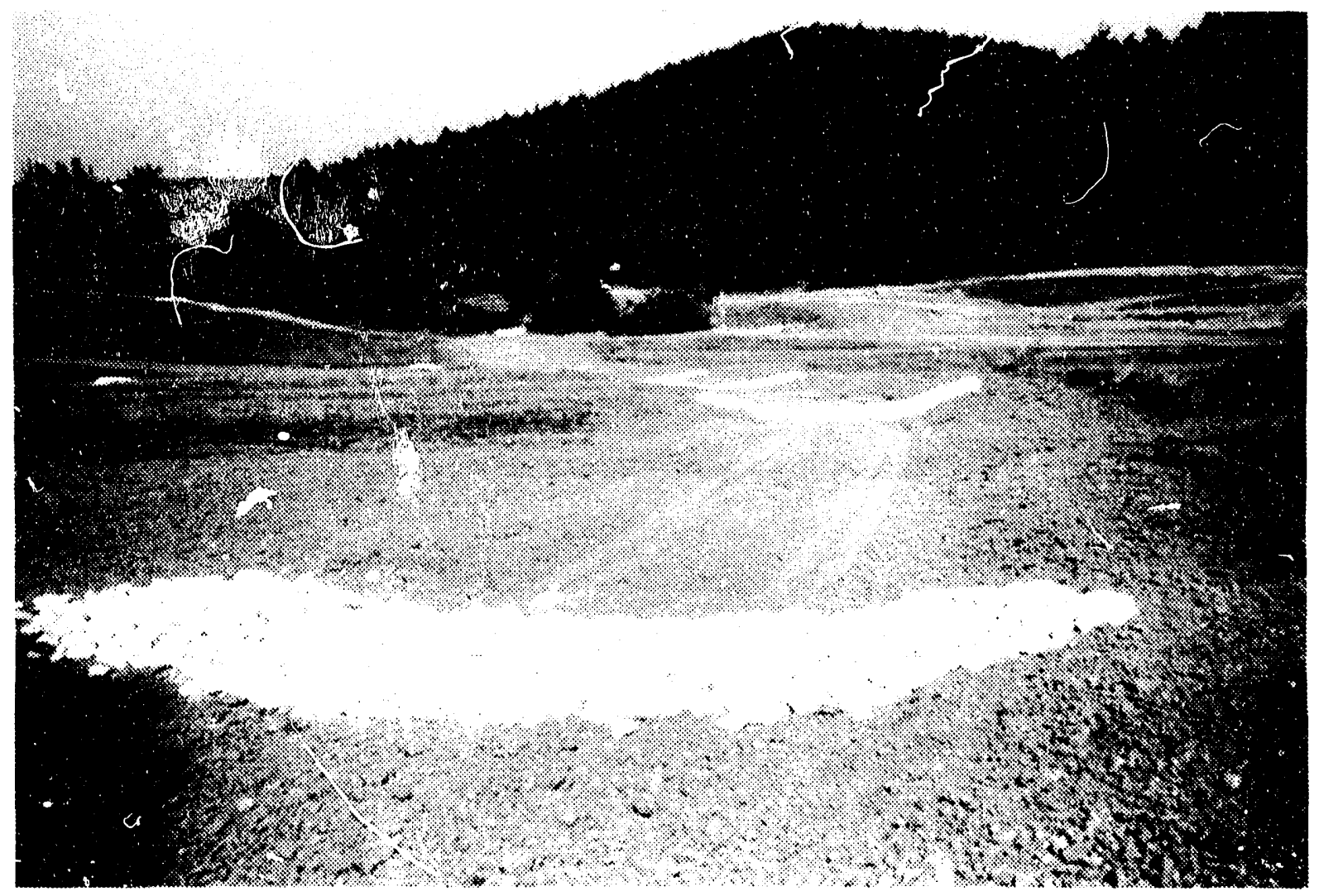

FIGURE 4 Appearance of Riprap Waterbars after Installation across a Waterway Channel at the Project Site

Prescription 10 involved the construction of large waterbars across tank trails in steeply sloped areas of the site. At a number of locations, tank trails ran directly down the slopes and crossed the ridges that were old field boundaries. The runoff that collected up-slope of these locations was channeled down the tank trail, thereby accelerating erosion. These waterbars were designed to reduce the velocity of the runoff, trap sediments, and discourage vehicle activity on the trails. The design and construction of the larger waterbars was similar to that in the waterway channels, except the berm of riprap was wider and higher.

Prescription 11 consisted of the construction of porous-riprap check dams in the main watercourse on the site. Drainage from the meadow was concentrated in a single drainage way. The purpose of the structures was to reduce the velocity of runoff, trap sediments, and prevent additional erosion in the main channel as runoff left the site. With the porous check-dam design, runoff could slowly drain from the dam $j$;ol after a runoff event, making the construction of a costly outlet structure unnecessary. The disign and construction of the porous check dams was similar to that of the large waterbars, with two exceptions. Dams were keyed into the floor of the channel, and a riprap apron was added on the downstream side to prevent scouring if the pool overflowed. 


\subsection{Prescription Implementation}

After the development of the 11 prescriptions for the Kange $8 \mathrm{C}$ project site, detailed specifications and drawings were prepared. The plans and specifications were reviewed by USACERL and HTA personnel, translated into German, and submitted to several local contractors for bids. Range $8 \mathrm{C}$ was closed to military use in August 1986, and prescriptions were implemented during September 1986, with ANL staff supervising the construction effort. During implementation of the prescriptions, detailed records were kept of the material, labor, and equipment use required for each prescription. During October 1986, a company of Combat Engineers rebuilt the access road from the North Tank Road to the meadow. This effort included the construction of a rock ford through the main drainage way. The development and the implementation of the rehabilitation prescriptions are described in detail in Zellmer et al. (1987). Range $8 \mathrm{C}$ remained closed for about one year, and then the site was reopened for military maneuvers in October 1987.

An evaluation to determine the effectiveness of each prescription or monitoring phase of the Range $8 C$ project began after prescription implementation in the fall of 1986 and continued through the spring of 1990. This document describes the methods used, data collected, and results of this monitoring phase of the Range $8 \mathrm{C}$ project. This document also includes recommendations for future rehabilitation efforts at training areas similar to HTA. 


\section{Goal, Objectives, and Approach}

The goal of the monitoring phase of the Range $8 \mathrm{C}$ project was to determine which cost-effective prescriptions would conserve natural resources and provide a safer, more realistic training environment with renewed military use of the site. The following objectives were established to achieve this goal:

- Monitor the establishment and survival of vegetative ground cover,

- Observe the effectiveness and durability of erosion control structures,

- Compare the environmental effectiveness and cost of prescriptions tested, and

- Recommend improved prescriptions for future rehabilitation efforts.

A program for periodic site inspections was developed to accomplish these objectives. Sire inspections and data collections were conducted each spring, summer, and fall, starting with the implementation of the prescriptions in th. fall of 1986 through the spring of 1990. During each inspection, the types and amounts of werd cover were measured on transects established in selected revegetation prescriptions. Data collected on ground cover during the initial year of the monitoring phase were used to measure the types and amounts of vegetation established by implementation of the prescriptions. Data from the following years provided information on the survival of vegetation with renewed military use of the site. Both types of data were to be used to develop revegetation practices and seed mixtures for future training area rehabilitation efforts.

Field observations were also made during each site inspection to evaluate the effectiveness of various types of erosion control structures installed at Range $8 \mathrm{C}$. The relative amount of sediments trapped and the effectiveness of the structures in preventing renewed erosion were noted. After the site was opened for military use, the damage to structures that was caused by military activities was assessed. This information would be used to suggest design changes for improving the effectiveness and durability of erosion control structures for use on training areas.

A record of site conditions was maintained by taking photographs and videotaping the site throughout the monitoring phase of the project. The photographs and videotapes were used to identify problems associated with individual prescriptions and to record the general condition of the site. This visual record also provided a means to estimate the long-term effectiveness of the Range $8 \mathrm{C}$ rehabilitation effort. The visual record was also useful to individuals who were not able to visit the site because they could see the changes that occurred before, during, and after prescription implementation. 
Data collected and field observations made during the monitoring phase of the project, combined with cost data collected during prescription implementation, were used to assess the relative economic effectiveness of each prescription. This information can be used to design and implement future training area rehabilitation programs that are environmentally and economically effecti"e. 


\section{Methods}

\subsection{Vegetation Studies}

Immediately after implementation of the prescriptions at the Range 8C site, 27 permanent transects for monitoring ground cover were established at nine locations on the site. Seven of the locations were representative of the revegetation prescriptions that were applied to large areas of the site, all of which had various soil conditions. Two reference areas were selected - the first was in an almost barren, compacted area, and the second was in an area unaffected by past training activities. The first control was used to measure the natural revegetation on a highly disturbed area, and the second control was used to monitor nati . vegetation changes on a relatively undisturbed area. Three $10-\mathrm{m}$ transects, to be used as replicates, were established at each location. The locations of the 27 transects were permanently marked so that investigators could make subsequent observations from the same locations during the monitoring phase of the project. Initial measurements of ground cover were taken after the prescriptions were implemented during September 1986. Additional measurements were taken each spring, summer, and fall through the spring of 1990, when the monitoring phase of the project was discontinued.

The point-intercept method (Chambers and Brown 1983) was used to measure the amounts of exposed soil, litter, and type of vegetation on each transect. A point-frame with 10 points or pins was used to determine ground cover at $1-\mathrm{m}(3.28-\mathrm{ft})$ intervals on the $10-\mathrm{m}-(32.8-\mathrm{ft}-)$ long transects (Figure 5). Exposed soil, litter, or the type of vegetation (i.e., grass, legume, fcrb) was recorded at each pin or observation point. Individual plants were identified to species when possible. The 10 frame settings of the 10-pin frame provided 100 observations from each transect, with each observation representing one percent of the transect area. Only the initial point of contact was recorded. During collection of the ground cover data, the number of transect segments (i.e., point-frame setting) damaged by recent vehicle traffic was also recorded.

A computer program was developed at ANL to process and summarize the field data in six categories: exposed soil, litter, grasses, forbs, legumes, and rye. A total vegetative cover category was calculated by summing the grass, forb, legume, and rye values. Total ground cover could te calculated by subtracting exposed soil values from 100 or by adding litter to total plant cover. Total ground cover values were not calculated or summarized because the exposed soil values are the inverse of the total vegetative cover values. The percent damage on each transect was calculated by summing the number of damaged segments on a transect and multiplying by 10 .

The general linear model (GLM) procedure of the SAS programs (Ray 1982) was used to statistically compare the seven categories of cover data. Analyses of variance of values expressed as percentages were not possible because percentages violate the assumption of variance homogeneity required for regression analysis. One solution to the variance homogeneity problem is a data transformation, and a normal transformation for percent values is the arc sine of the square 


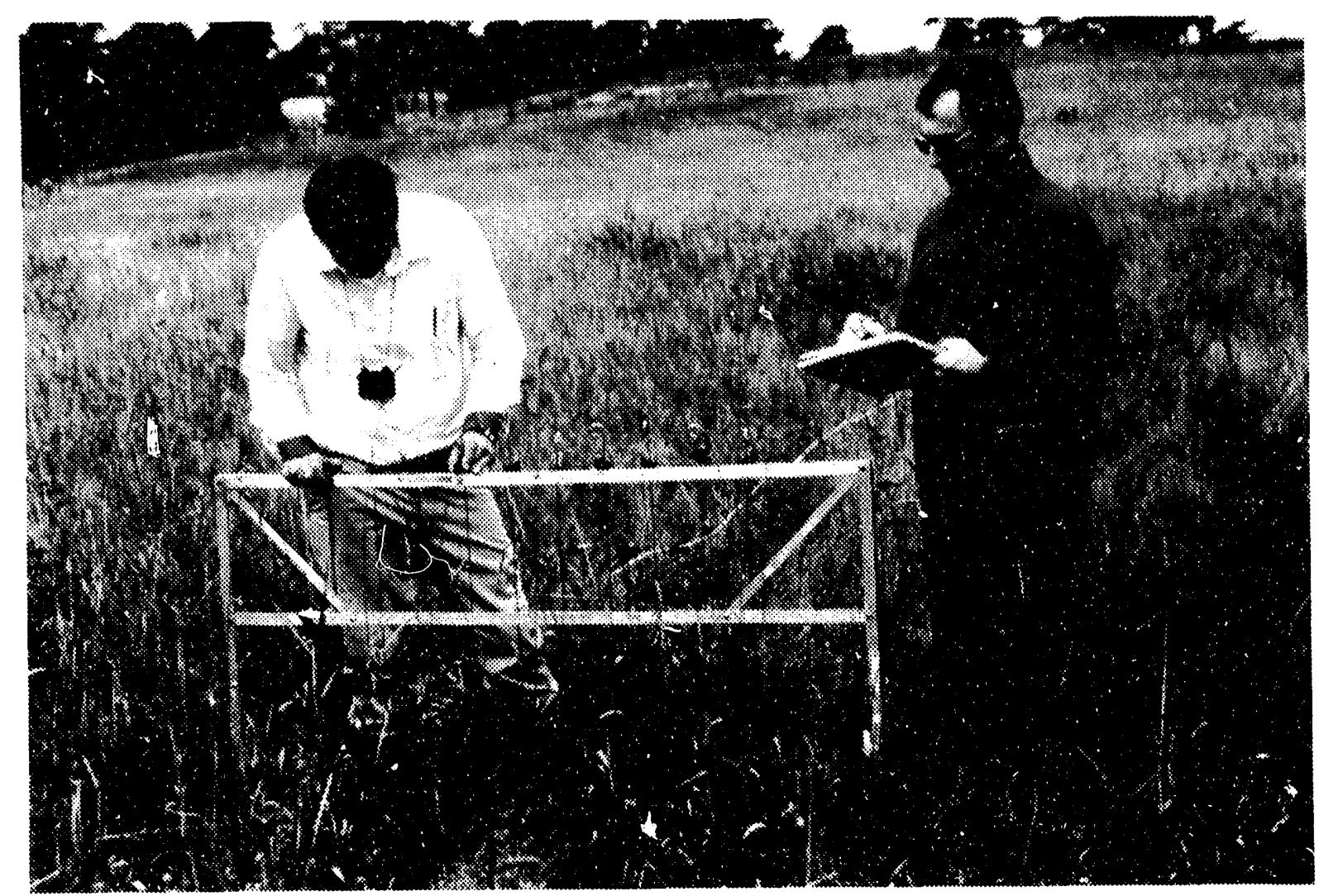

FIGURE 5 Collection of Ground Cover Data by the Point-Intercept Method Using the PointFrame at the Project Site

root of the percent value expressed as a decimal fraction.* This transformation tends to stabilize the variance and normalize the percent values. Another statistical analysis problem was maintaining a 0.05 level of significance while making multiple $t$-test comparisons (one location versus all other eight locations). This multiple-comparison problem was resolved by using Sidak's pairwise $t$ tests (Miller 1966), which enable pairwise $t$ tests on differences between means, with levels adjusted according to Sidak's inequality for all means. The procedure maintains a 0.05 level of significance for comparisons among multiple means.*

\subsection{Structure Monitoring}

Field observations were recorded during each site visit to estimate the effectiveness of the erosion control structures, and ground cover data were collected. These observations were not quantitative measurements of the amount of sediment trapped by either waterbars or porous check

*Carnes, B.A., 1984, personal communication, Biostatistician, Biological and Medical Research Division, Argonne National Laboratory, Argonne, Ill. 
dams or of the extent to which the terrace and waterway systems reduced erosion and the volume and velocity of runoff. Observations were made to determine if the waterbars and porous check dams had trapped sediments and slowed runoff. Terrace and waterway channels were examined for erosion and sediment deposition. After Range 8C was reopened in September 1987, all structures were examined to determine if damage had been causeci by military vehicles during training maneuvers. The condition of the structures indicated the durability and suitability of each type of structure for use on active training areas. During each site visit, the structures and the site were photographed and videotaped to provide a visual record that could be used for later reference.

\subsection{Cost Analysis}

Data collected during implementation of the prescriptions were used to estimate the relative cost of each prescription. The contractor provided information about the cost of materials (fertilizer, seed mixtures, soil stabilizer, and riprap), including the cost of delivery of the materials to the site and any associated storage charges. The cost for prescription operations was calculated by subtracting material costs from the bid price for the operation. All costs were adjusted to an area or unit basis so that the relative cost of each material, operation, and prescription could be determined. All economic data are 1986 values, and no adjustment has been made to future values. Cost information was combined wili the results of field observations made and ground cover data collected during the monitoring phase of the project to determine the practicality of each prescription implemented at the Range $8 \mathrm{C}$ site. 


\section{Results and Discussion}

\subsection{Vegetation Studies}

One objective of the monitcring phase of the Rar ge $8 \mathrm{C}$ project was to determine the types and amounts of vegetative ground cover established by implementing the prescriptions (and, at the same time, to monitor the durability and survival of the ground cover with renewed military use of the site). The amounts of ground cover (vegetative cover plus litter) and exposed soil have been shown to be highly correlated with erosion rates and soil stability (Hoffman et al. 1983; Meeuwig 1970). All types of vegetative cover, however, do not provide equal erosion protection and soil

stabilization. Grasses are usually considered better than most forbs for erosion control (Wischmeier and Smith 1978) because grasses have multiple stems and fibrous root systems that bind and hold soil particles, thereby preventing soil erosion. Forbs usually have a single stem and often have a shallow root or taproot system that does not bind the soil as well as grass roots do. Dormant grasses tend to remain intact and rooted in the soil, whereas the aboveground parts of dead forbs tend to break up into loose, unattached litter at the end of the growing season. The establishment and maintenance of a vegetative ground-cover community with a high proportion of grass is an important factor for controlling erosion and providing a safer, more realistic training environment on training areas.

Ground cover data were collected at regular time intervals by using the point-intercept method. Only the initial contact of the pin was recorded to provide an accurate representation of the relative amounts of exposed soil, litter, and vegetation. Recording only the initial contact of the pin can, however, bias the species composition data against shorter species of plants because the initial contact of the pin is usually with the taller species of plants. The initial contact of the pin does indicate if raindrops would be intercepted by the exposed soil, litter, or vegetation (a primary factor intluencing erosion rates is the interception of raindrops).

The implementation of the different prescriptions resulted in differences in the types and amounts of vegetation established, as indicated by the means for each cover category (e.g., exposed soil, litter, and grass) for a given collection date during the initial year of monitoring. Significant differences among the means of each category for different prescriptions indicate differences in the effectiveness of prescriptions in establishing ground cover and controlling erosion. By comparing the data from a given prescription with the means from previous collection dates, the rate and direction of change in the types and amounts of ground cover can be determined. This information indicates the influence of military activity on the ground cover community. The presen e or absence of statistically significant differences may not always reflect differences observed in the field. If replicate (transect) values for a category are relatively uniform, a comparatively small numeric difference between prescription means can result in a significant statistical difference. Small numeric but significant statistical differences may not indicate practical differences with respect to erosion control or other important factors, including the quality and quantity of the vegetative community. Conversely, large numeric differences among means may not be statistically significant because of large numeric differences among 
replicate (transect) values within the category. A major factor causing large numeric differences among replicate (transect) values at the Range $8 \mathrm{C}$ site was damage caused by military traffic. Traffic on transects was not uniform, and during vegetation monitoring, the number of damaged segments on each transect was noted. The data were used to calculate the average percent damage for the area ar.d to provide a general indication of the relative amount of traffic on the transect. The relative amount of traffic and damage provides an indication of the types and amounts of vegetation that survived on the site with renewed military use.

Initial collections of ground cover data were made after the implementation of the prescriptions in 1986. Additional data were collected each spring, summer, and fall through April 1990. Data from seven ground-cover categories and the percent damage for each collection date were statistically analyzed to compare the seven prescriptions with each other and the two reference areas. Analyses of variance, based on the GLM procedure of the SAS programs (Ray 1982), were conducted for each collection date on transformed category percent values, with the arc sine of the square root of the percent value expressed as a decimal fraction. Table 1 lists the mean percent cover by the seven cate ${ }_{2}$ ory areas and percent damage for the seven prescription and two reference areas for the 11 data collections. Statistically significant differences among the percent cover data for the 11 collection dates within a given category for each prescription area are indicated.

Although the site was officially closed from September 1986 through September 1987, there was some military use of the site during this period, and the damage that resulted from this activity prevented or destroyed ground cover on some transects. Nevertheless, even with military traffic, the percent grass cover increased on all areas during this period. The percent grass cover was significantly higher after one year on the four prescription areas that had little or no grass cover when the prescriptions were implemented. The amount of grass cover on once-barren prescription areas that were fertilized and seeded was substantially higher than the amount of grass cover on the natural revegetation reference area, indicating that fertilization and seeding aided in the establishment of grass cover. Grass cover also increased substantially on the three prescription areas with existing vegetation, but the increases were not statistically significant. A comparison of the percent grass cover on the native vegetation reference area with the percent grass cover on prescription areas that had existing vegetative cover and that had received fertilizer shows that the proportion of grass in the stand was increased by fertilization; therefore, fertilization may have increased the proportion of grass in an established stand of vegetation. The proportion of grass in the native vegetation did not change during the initial year of monitoring. The percent grass cover on the natural revegetation area also increased substantially during this period, but not significantly, indicating that natural revegetation does occur, but the rate at which grass becomes established is slow.

Differences among prescriptions receiving different methods of seedbed preparation (i.e., seeding only, tillage, and level, rip, and till) were not evident in the percent grass or other vegetative cover established. A barren area adjacent to the newly constructed access road was broadcast seeded without fertilization or seedbed preparation during October 1986. Although this area was not monitored, the types and amounts of vegetation established appeared to be equivalent to those established on prepared seedbeds at the site. This observation, along with data from the 


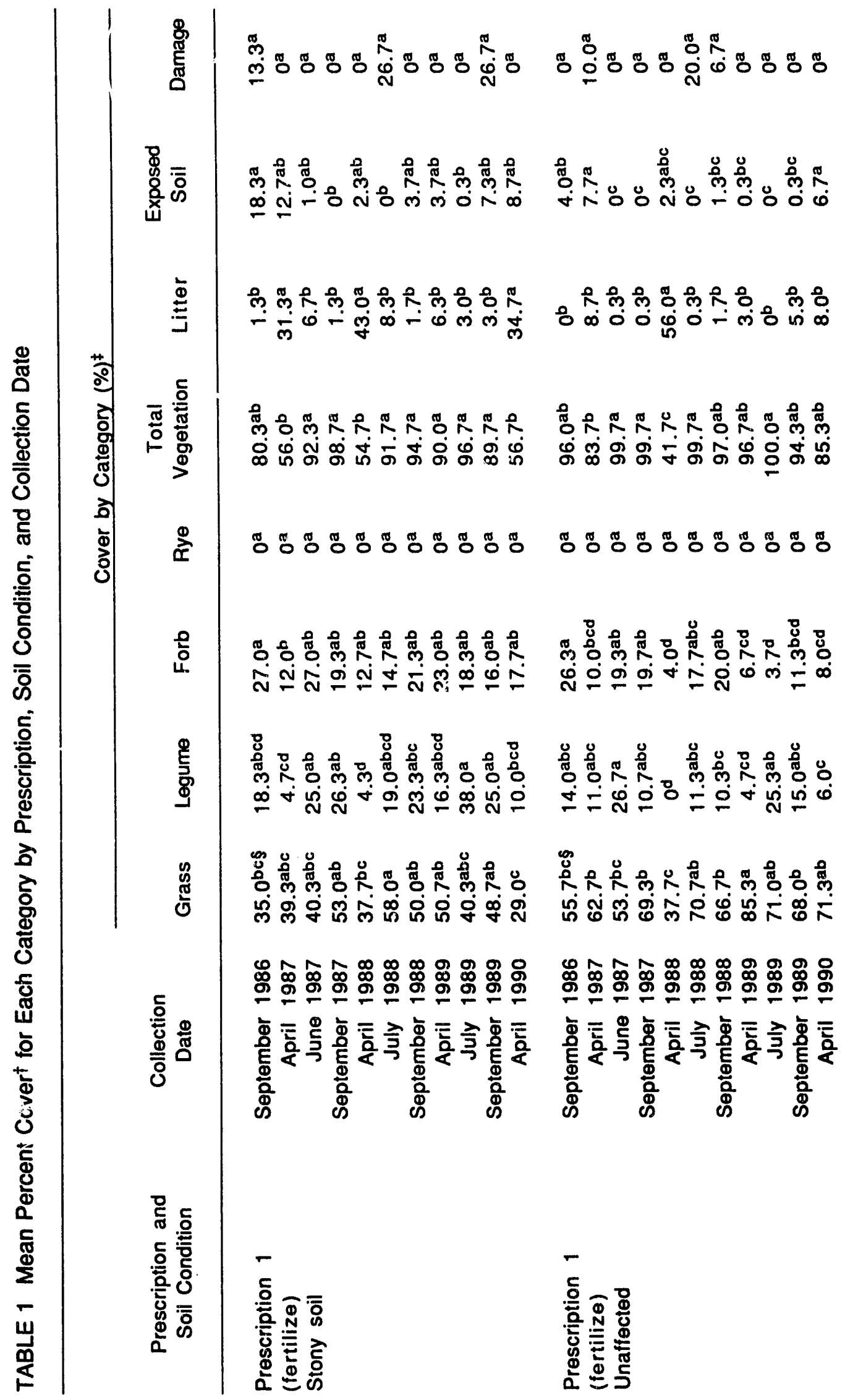




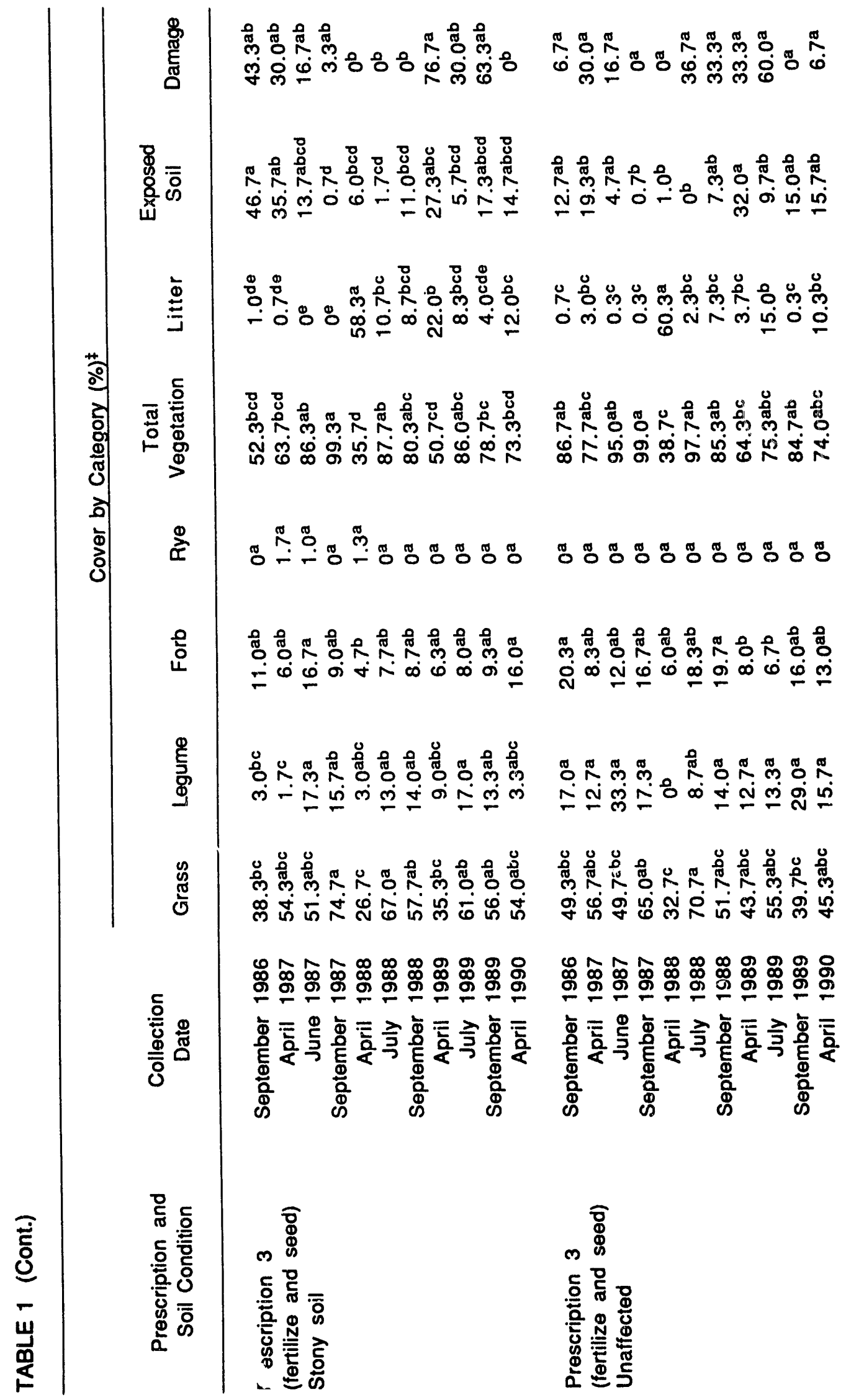




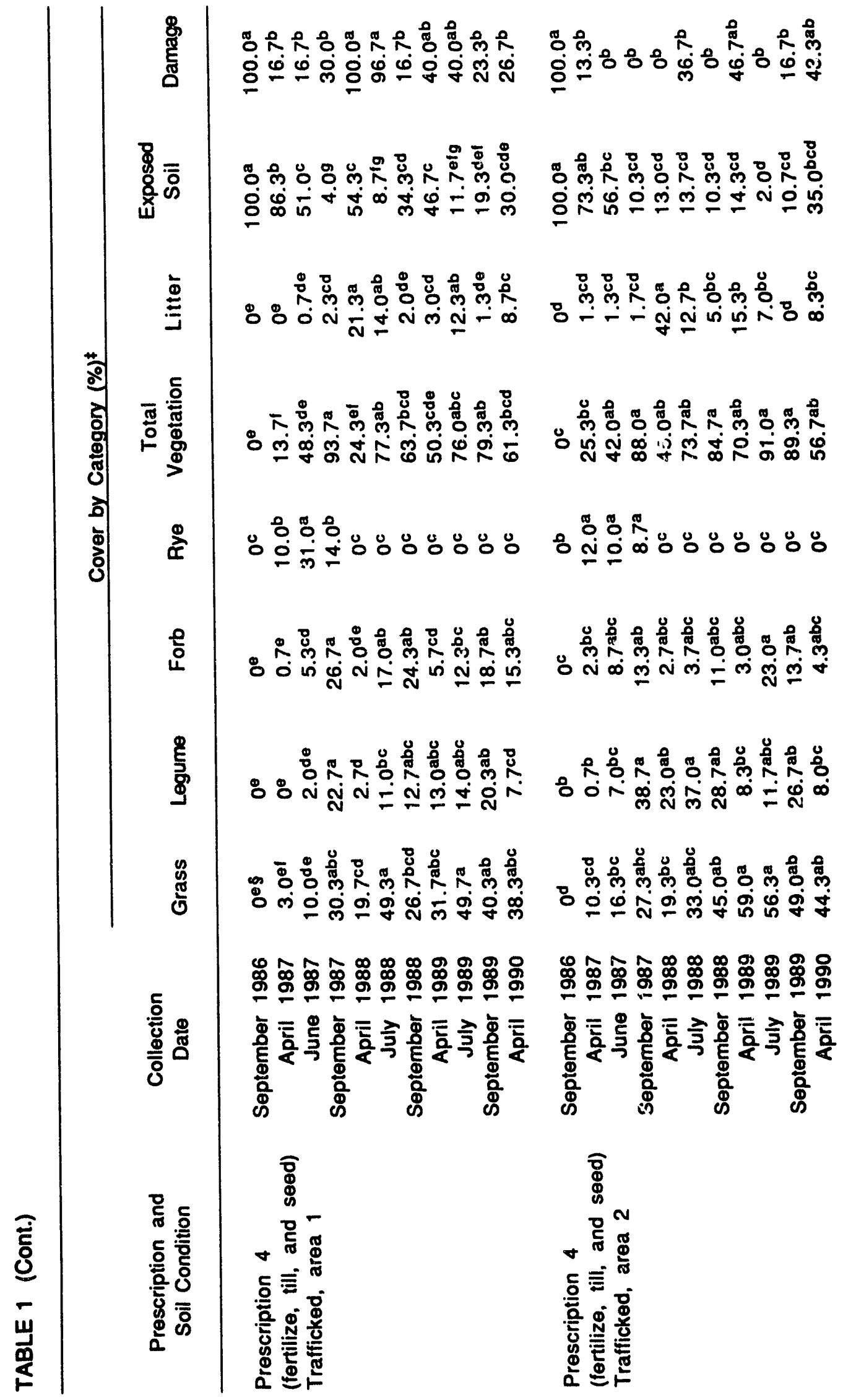




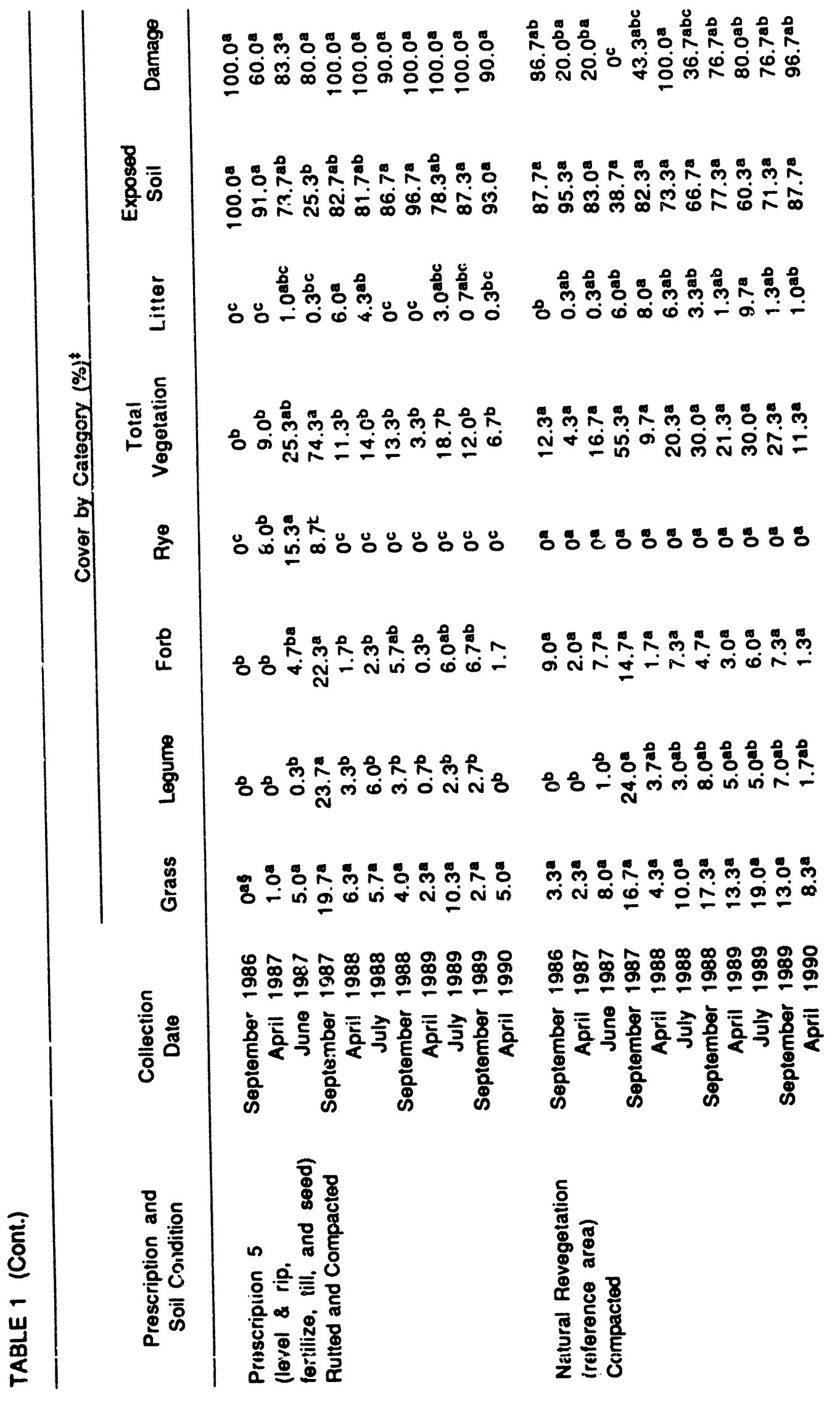




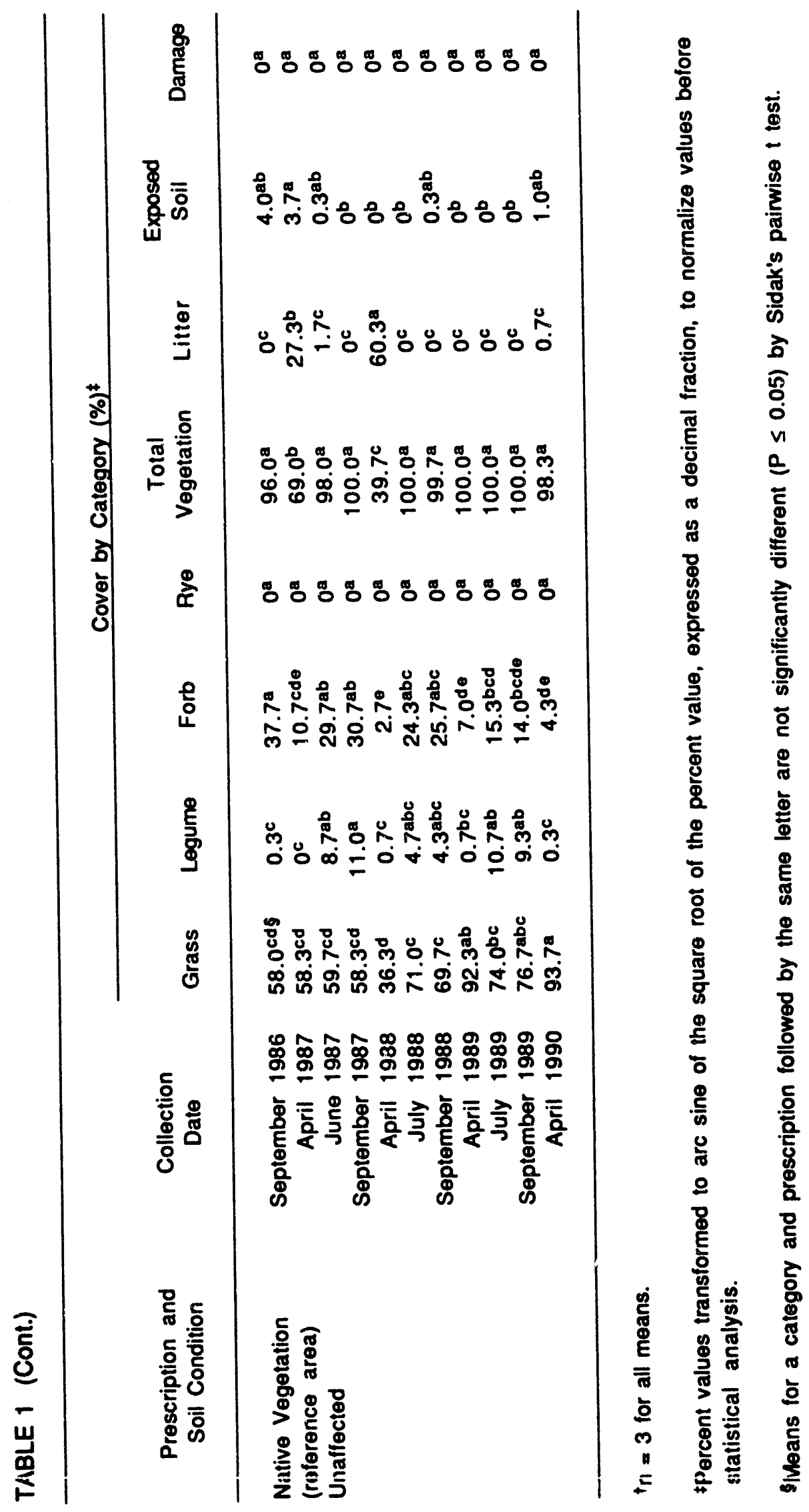


prescription areas, indicates that the method of seedbed preparation did not influence grass establishment as much as did a source of seed.

A review of all vegetative cover data indicates that the amount of grass and vegetative cover is directly related to the degree of damage and traffic. The percentage of grass cover and total vegetation was lowest during the spring (April) monitoring sessions, and grass cover increased (along with total vegetative cover) throughout the growing season. If damage did not occur in the monitoring area, the percentage of grass cover increased through the fall monitoring session. The amount of grass cover decreased proportionally to the relative amount of damage, but if damage did not reoccur, the percentage of grass cover increased during the following monitoring session. These observations indicate that grasses regrow from established root systems and that the redevelopment of grass cover from established root systems is faster than the redevelopment of grass cover from seed. The rate at which grass cover recovers is an important factor in erosion control on training areas. The presence of grass is indicated by the presence of some grass cover on the prescription area that received $90 \%$ or more damage during the three years of monitoring with military use of the site. The amount of grass cover remaining on different prescription areas does not appear to be related to prescription components but to the degree of damage to an area. The data do, however, indicate that fertilization and seeding increased the amount of grass established and that some grass cover remained so that erosion was controlled, even with renewed use of the site.

Legumes responded somewhat differently to the prescriptions than did the grasses. In prescription areas with existing vegetation, fertilization generally did not increase the percentage of legume cover. In prescription areas with little or no existing vegetation, legume cover generally did not develop until after the development of grass cover, and legumes were not a substantial portion of vegetative cover until one year after seeding in the fall of 1987 . The amount of legume cover established on the seeded prescription areas was not appreciably different than that established on the natural revegetation area. This phenomenon suggests that fertilization and seeding may not have substantially increased the percentage of legume cover above the amount that would have been established by natural revegetation. The percent legume cover in the seeded prescription areas is, however, generally higher than that in (1) existing stands of vegetation that had been fertilized and (2) the native vegetation reference area. As with grasses, the type of seedbed preparation appears to have little influence on the amount of legume cover established.

Legumes responded much like grasses after renewed military use of the site. Legumes also appeared to recover after damage, and regrowth occurs from established root systems. Unlike grasses, the percent legume cover generally did not increase after the area was damaged by military activity, indicating that damage may have a more lasting influence on legumes than on grasses and lower their survival rate. The complete elimination of legumes within three years from the stand in the prescription area that received continued and heavy damage also indicates that the legumes are more sensitive than grasses to disturbances. Therefore, it may be easier to establish and maintain grasses rather than legumes on training areas. 
Forbs, other than legumes, were not inciuded in the seed mixtures, but they did appear on all the prescription and reference areas in a proportion approximately equal to legume cover. The relatively high proportion of forbs indicates that a substantial source of forb seeds may be present in adjacent areas or in the soil seed bank. A substantial increase in forb cover on the native reference area during the initial year of monitoring indicates the presence of a significant source of seeds. Generally, forb civer decreased on the fertilized and seeded prescription areas from 1986 to the fall of 1987, and this decrease was probably due to the increased growth of and competition with the fertilized grasses. On previously barren prescription areas, the percent forb cover increased significantly during the initial year of monitoring, probably because of reduced military traffic on the site.

Some forb cover was observed on all the prescription areas throughout the study, indicating the persistence of forbs in the vegetative community. Like grasses and legumes, the percent forb cover decreased as the percent damage increased, and the percent forb cover increased with reduced damage. Forbs are persistent, as indicated by the presence of forb cover on transects that received continued and heavy damage for three years. Because many forbs, other than legumes, are less than ideal for erosion control (and because forbs are becoming established on training areas), there appears to be no need to include forbs in the seed mixture.

Cereal rye was included in the meadow seed mixture because it can quickly cover the area and control erosion while perennial grasses and legumes become established. As expected, rye was the dominant cover during April 1987 on all prescription areas that had little or no vegetative cover when the prescriptions were implemented. Rye cover generally increased through June and decreased by September 1987 on these areas. Although the cereal rye set seed, it did not generally become reestablished the following year and was only observed in one prescription area in 1988. Rye was not recorded on seeded areas with substantial stands of existing vegetation, indicating that it is not a good competitor in a thick stand of existing vegetation. Cereal rye provided soil protection and erosion control during the winter following seeding, but because of the lack of reestablishment and persistence in the stand, it may have been better to use another species to provide quick cover.

In contrast to the fall of 1986 , the percent total vegetative cover was significantly higher on all prescription areas in the fall of 1987 . The most dramatic increases in vegetative cover were on areas that were barren before the prescriptions were implemented, but significant and substantial increases were also observed on some prescription areas that had existing vegetative cover and were fertilized and seeded. The increase in grass cover was the major factor contributing to the increases in vegetative cover. The increases in vegetation indicate that all of the prescriptions were successful in establishing or increasing vegetative cover. Although some increase in vegetative cover was observed in the native vegetation reference area, this increase was not statistically significant. A rather dramatic increase was also observed in the mean vegetative cover on the natural revegetation, but this increase was also not statistically significant. The uneven distribution of vegetation on the transects accounts for the lack of statistical significance. The patchy distribution of vegetation is typical of the natural revegetation process, and it results in inadequate vegetative cover and thus ineffective erosion control. 
With renewed use of the site starting in September 1987, there was a general decrease in vegetative cover because of damage in several of the prescription areas. The amount of the decrease in vegetative cover was related to the degree of damage observed on the transects, and a significant decrease in vegetative cover was observed on areas that received heavy traffic. One prescription area that had $75 \%$ cover in the fall of 1987 had only $11 \%$ vegetative cover in the spring of 1988. In contrast, other prescription areas that were originally barren had $50 \%$ or more vegetative cover after three years of military use. These variations indicate that (1) damage is probably cumulative and (2) several years of heavy damage are required to completely destroy vegetative cover over a large portion of a site. Nevertheless, no prescription can maintain vegetative cover on heavily trafficked areas.

The percent litter was the highest during the April 1988 monitoring season, which was after the year when vegetative cover was the highest and military use of the site had been renewed. The measurements of percent litter were generally lower on areas with established vegetation than on areas with less vegetation because the pin of the point-frame struck standing vegetation before it reached the litter layer. The highest percent litter was generally observed in the spring, before renewed growth of vegetation. The aforementioned observations indicate that the production of litter is important because litter protects the soil surface and controls erosion during the winter and early spring, before active plant growth. On heavily damaged areas with limited vegetative cover, litter production was low, and the small amount of litter produced was probably destroyed by traffic.

The percent exposed soil on the seven prescription areas decreased in the year after the prescriptions were implemented (generaily, the amount of exposed soil in September 1987 was significantly lower than that in September 1986). The percent exposed soil decreased from April through September 1987 because vegetative ground cover became established, but significant differences were generally not observed until September, the end of one growing season. A decrease in the percent exposed soil was also observed on both reference areas. The decrease of almost $40 \%$ in exposed soil on the natural revegetation reference area was not significant because exposed soil and vegetation were patchy, producing wide variations among transect values.

As expected, the amount of exposed soil generally increased with renewed military use of the site starting in September 1987 and is related to the percent damage on the transects. The percent exposed soil was highest during the April monitoring session, indicating that erosion rates were probably highest during winter and early spring rains. A comparison of September 1986 values with September 1989 values shows a decrease in the percent exposed soil on most prescription areas, indicating that implementation of the prescriptions had increased ground cover and reduced the rate of soil erosion at the site.

\subsection{Structure Monitoring}

A second objective of the monitoring phase of the Range $8 \mathrm{C}$ project was to observe the effectiveness and durability of various types of erosion control structures installed at Range $8 \mathrm{C}$. 
Grassed waterways with riprap waterbars, a terrace system, riprap waterbars across tank trails at old field boundaries, and porous check dams were constructed to slow the velocity of runoff and trap sediments. Field observations were made during the collection of ground cover data to determine the effectiveness and durability of these types of structures. The results of these observations were used to determine the practicality of the structures in the rehabilitation of tactical training areas.

The grassed waterway system was designed to reduce the velocity of runoff as the water traveled down the slopes of the site. Before the waterway system was constructed, runoff had concentrated in old tank ditches and defined channels that had developed into deep gullies. By replacing the gullies with wide, vegetation-lined channels, the velocity of the runoff could be reduced and the redevelopment of gullies could be prevented. Riprap waterbars, constructed across the waterway channels, were designed to further reduce the velocity of runoff and trap sediments. In addition, the waterway system provided outlets for the graded terrace system.

As previously stated, the site was officially closed to military use for one year after the implementation of the prescriptions. Nevertheless, there was some military use of the site during this period. The first and most obvious evidence of military use was in the grassed waterways. On the basis of observations made during the April 1987 site inspection, it was apparent that both wheeled and tracked vehicles had used some of the waterways as roads because vehicle tracks were evident in several waterways. Traffic had occurred during the winter (before vegetation was established), creating two parallel ruts that spanned the entire length of the waterways. Runoff from the terrace system was directed into the waterways; without protective vegetative cover, the two tracks concentrated the water flow, leading to the development of rills. The riprap waterbars across the waterways slowed the runoff and trapped some sediments. The waterbars also prevented cutting in the waterway channel and the redevelopment of gullies. These early observations indicated that grassed waterways were not suitable for erosion control on training areas.

Traffic and the use of the waterways as roads also reduced the effectiveness of the graded terrace system. The function of a graded terrace system was to divert extended overland flows of runoff by reducing slope lengths. Runoff from the upper slope collected in the terrace channel and was diverted, at a lower velocity, into an outlet (waterway) that carried the water off the slope. Observations made during the initial year of monitoring at Range $8 \mathrm{C}$ indicated that the graded terrace system was functioning as designed and that the extended overland flows of runoff from the upper slopes were intercepted. Some sediments were deposited in the terrace channel because the velocity of the runoff was reduced. Because vehicles damaged the grassed waterways, there was no acceptable outlet for the terrace system, which made the future use of graded terraces on training areas impractical.

The riprap waterbars installed across old tank trails at old field boundaries were also designed to reduce the velocity of the runoff, trap sediments, and discourage the use of the tank trails. Some of the tank trails ran directly down the steep slopes, and trails above and below the waterbars were fertilized and seeded when the waterbars were installed. The amount of sediments 
trapped by these wat erosion on the tank trails. The velocity of the runoff on these trails was reduced, as indicated by the lack of renewed erosion below these structures.

The porous check dams were also designed to reduce the velocity of the runoff and trap sediments in the main drainage channel. Because of the design of the porous check dams, the dam pools could drain between periods of runoff. Solid check dams constructed at other locations on the HTA were often full of water and provided no retention time to reduce sediment loads from an additional or large runoff event due to overflow. The first porous check dam in the main drainage channel trapped the most sediment at a depth of about $15 \mathrm{~cm}(6 \mathrm{in}$.) by June 1987. The amount of sediment in each dam down the channel was reduced, and the lowest of the five dams had no deposition of sediment. No standing water was observed in the dam pools for several days after a runoff event, indicating that the dam pool had drained after runoff events.

On July 2,1987 , the site and nearby area received a record rainfall that flooded villages in the valley adjacent to the site. This storm was estimated to be a 100-year rainfall event; unfortunately, all structures had been designed for a 25 -year rainfall event. Observations were made by USACERL personnel to determine the condition of the erosion control structures at the site immediately after the rainfall event. There was evidence of high levels of runoff flow in the terrace and waterway channels and new erosion in the waterway channels. The waterbars across the waterways had prevented cutting and extensive erosion, as well as the redevelopment of gullies. There was no evidence of renewed erosion below the waterbars that blocked the old tank trails, indicating that these structures had survived the storm without damage. Nevertheless, several of the porous check dams in the main drainage channel had been damaged by the high levels of runoff flow. The first check dam sustained the most damage, with each successive downstream dam receiving less damage. Water flowing over the check dams had dislodged some of the smaller riprap and washed it down the main drainage channel. The damage to the structures caused by the storm indicates that riprap should be larger to prevent it from becoming dislodged and carried away during high water flows.

The site was reopened to military use in September 1987, and the structures were exposed to potential damage by vehicles. During the three years after the site was reopened, tank trails redeveloped across the site. Most of the trails redeveloped in the same general location as the prerehabilitation trails, and one major trail did develop in one of the waterways. The waterbars across the waterway did not appear to discourage traffic on this trail, but the waterbars did prevent extensive erosion, cutting, and redevelopment of a gully. Vehicles crossed the terraces, but no major damage to the terraces was evident after three years. The major problem with the terrace system was the lack of a controlled runoff outlet. The waterbars across the old field boundaries apparently discouraged traffic, and these trails generally did not redevelop. Vegetation developed on the old trails above and below these structures, stabilizing these areas. The porous check dams in the main drainage continued to trap sediment, even after the dams were damaged by the record rainfall. There was evidence that tracked vehicles had occasionally crossed several dams, but the vehicles did not cause any damage that would impair the function of these structures. 


\subsection{Cost Analysis}

A third objective of the monitoring phase of the Range $8 \mathrm{C}$ project was to compare the environmental effectiveness of each prescription with its cost. Because of the wide variation in costs attributable to the local availability of materials, labor, and equipment used, the economic data presented here should be useci only for comparison. All costs reflect the price paid to the contractor in 1986 and include contractor overhead, charges for supervisory personnel, mobilization and demobilization costs, and contractor profit. Beçause the costs are locationspecific, the cost data given in this report may not reflect the cost of future rehabilitation at HTA or the cost of similar operations at other locations.

The costs for the individual prescriptions given in Table 2 are based on the bid prices of the contractor. The costs for the revegetation prescriptions (prescriptions 1-7) are given in a perhectare basis so that they can be easily compared. Because each meter of terrace or waterway differed in topography and therefore required varying amounts of earth moving, earth-moving costs for terraces and waterways are an average cost per meter for the entire prescription area. The costs of terraces and waterways do not include the costs of fertilization, tillage, and seeding because these operations were included in the area treated with prescription 4 . The cost of a waterbar given in prescription 9 (Table 2) is the average cost of installing 29 waterbars of this type. The total cost of waterway construction is an average cost per meter for the entire system and includes the cost of the waterbars. The costs of the larger waterbars and porous check dams are also the average costs of installing each type of structure.

Table 3 provides the average unit cost of materials used during the rehabilitation effort. These costs were provided by the contractor. Fertilizer and seed costs include charges for the transportation of the materials to and their storage in a local warehouse prior to use. Charges for the riprap include the cost to transport the riprap from a local quarry about $15 \mathrm{~km}(9.3 \mathrm{mi})$ from Range $8 \mathrm{C}$ to the site where the waterbars and check dams were to be constructed. Table 4 gives the average unit cost for the labor and equipment required for the various operations to implement the prescriptions. The costs of individual operations were calculated by subtracting material cost (Table 3) from the bid price for an individual prescription (Table 2). (Costs were originally in Deutsche marks and converted to U.S. dollars by using the 1986 rate.)

Ground cover data indicate that fertilization and seeding were major factors in the reestablishment of acceptable vegetation to control erosion at Range $8 \mathrm{C}$. On the basis of the lower costs of prescriptions 1,2, and 3 (compared with the other revegetation prescriptions), application of fertilizer and seed appears to be an efficient method of reestablishing ground cover. Data in Table 3 indicate that labor and equipment use account for more than one-half of the total cost of prescriptions 1,2, and 3. Because labor and equipment often represent a considerable portion of the total cost, the application of sufficient quantities of fertilizer and seed during initial rehabilitation is important. The costs of fertilization (Table 4) were less than those for seeding because the fertilizer was broadcast while much of the area was drill seeded. The costs of prescription 2 (broadcast seeding) and prescription 3 (drill seeding) probably differed, but the differences were 
TABLE 2 Average Cost per Unit of Prescriptions Used at the Range 8C Site

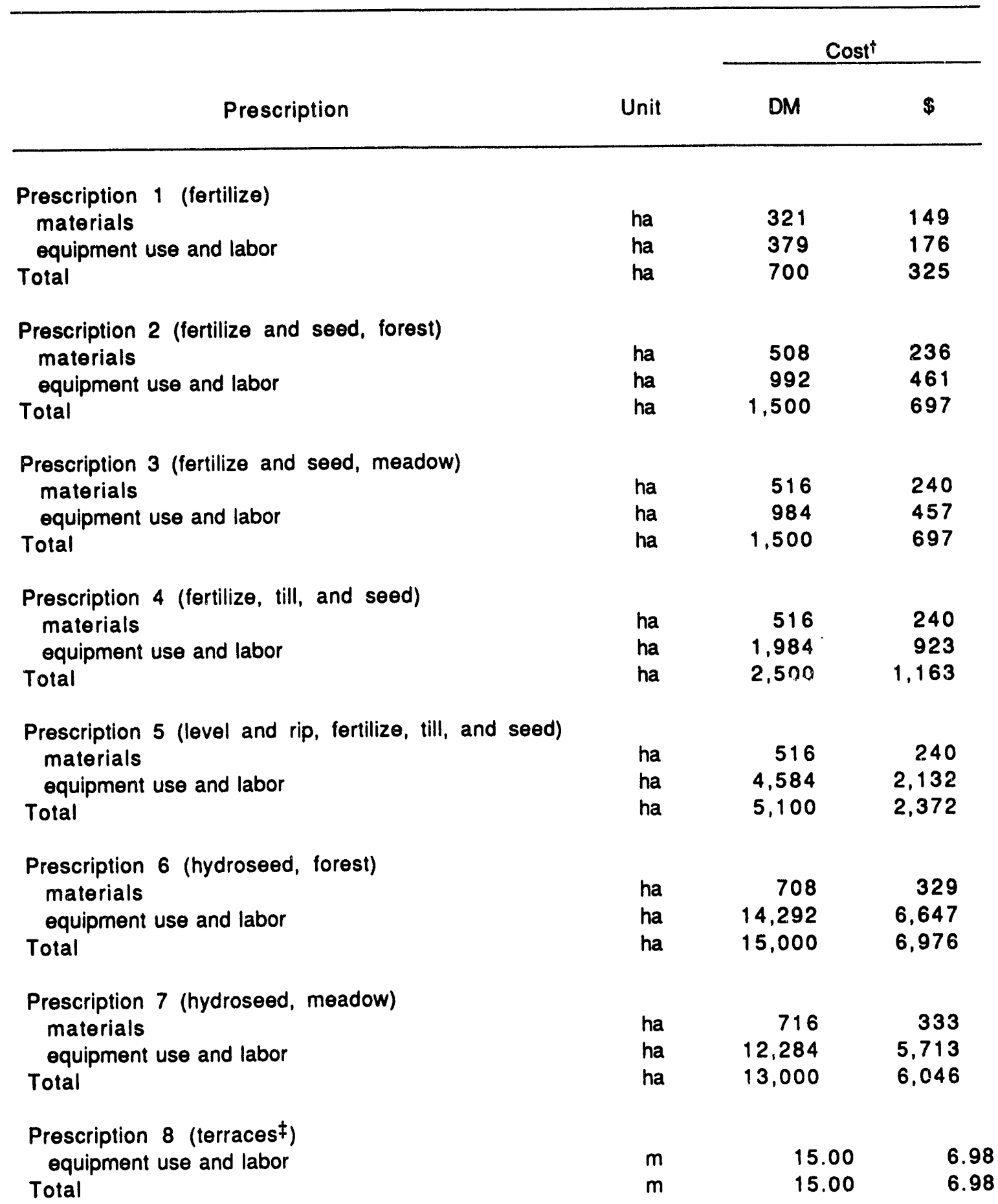




\begin{tabular}{|c|c|c|c|}
\hline \multirow[b]{2}{*}{ Prescription } & \multirow[b]{2}{*}{ Unit } & \multicolumn{2}{|c|}{ Cost $^{\dagger}$} \\
\hline & & DM & $\$$ \\
\hline \multicolumn{4}{|l|}{$\begin{array}{l}\text { Prescription } 9 \text { (waterways } \$ \text { ) } \\
\text { arading }\end{array}$} \\
\hline $\begin{array}{l}\text { equipment use and labor } \\
\text { waterbar construction }\end{array}$ & m & 7.50 & 3.49 \\
\hline material & structure & 30.00 & 1.09 \\
\hline equipment use and labor & structure & 35.00 & 8.09 \\
\hline Totaltt & m & 24.70 & 11.49 \\
\hline \multicolumn{4}{|c|}{ Prescription 10 (waterbars across tank trails) } \\
\hline materials $¥ \ddagger$ & structure & 111.00 & 51.63 \\
\hline equipment use and labor & structure & 129.50 & 60.23 \\
\hline Total & structure & 240.50 & 111.86 \\
\hline \multicolumn{4}{|l|}{ Prescription 11 (porous check dams) } \\
\hline materia|\$\$ & structure & 942.00 & 438.14 \\
\hline equipment use and labor & structure & $1,099.00$ & 511.16 \\
\hline Total & structure & 2,041 & 949.30 \\
\hline
\end{tabular}

†2.15 DM $=\$ 1.00$.

¥Average $2 \mathrm{~m}^{3}$ per meter of terrace, terraces fertilized, tilled, and seeded under prescription 4.

\$Average $1 \mathrm{~m}^{3}$ per meter of waterway, $1 \mathrm{~m}^{3}$ riprap per waterbar, waterways fertilized, tilled, and seeded under prescription 4.

${ }^{\dagger+}$ Average cost of 1150-m waterway constructed.

¥¥Average of $3.7 \mathrm{~m}^{3}$ riprap per waterbar.

${ }^{\$ 5}$ Average of $31.4 \mathrm{~m}^{3}$ riprap per check dam. 
TABLE 3 Average Cost per Unit of Materials Used during the Rehabilitation of the Range $8 \mathrm{C}$ Site

\begin{tabular}{lllll}
\hline \multicolumn{1}{c}{ Material } & & \multicolumn{2}{c}{ Cost $^{\dagger}$} \\
\cline { 3 - 5 } & Unit & DM & $\$$ \\
\hline Fertilizer (458 kg/ha) & ha & $321^{\ddagger}$ & 149 \\
Forest seed mix (42 kg/ha) & ha & $187^{\ddagger}$ & 87 \\
Meadow seed mix (62 kg/ha) & ha & $195^{\ddagger}$ & 91 \\
Soil stabilizer for hydroseeding & ha & $200^{\ddagger}$ & 93 \\
Riprap for waterbars and check dams & $\mathrm{m}^{3}$ & $30^{\ddagger}$ & 14 \\
\hline
\end{tabular}

†2.15 DM $=\$ 1.00$.

\#Cost includes storage and delivery to site, rounded to the nearest Deutsche mark and dollar.

not reflected in the bid price of the contractor. On the basis of the results of the ground cover monitoring and the prescription costs, prescriptions 1,2 , and 3 appear to be acceptable revegetation methods.

Prescription 4 was more expensive than prescriptions 1,2, and 3 because the tillage operation was added to prescription 4 . The vegetation data, however, indicated that tillage did not increase the amount of ground cover that was established. The costs for prescription 4 are relatively high because of the microtopography of the area and the potential for damage to the equipment. Prescription 5 was twice as expensive as prescription 4 because of the equipment time required for ripping and leveling. Compared with other prescriptions, ripping and leveling did not produce a measurable increase in vegetative cover. Because tillage (including ripping and leveling) was relatively expensive and ineffective, it is not considered an economically feasible operation in this rehabilitation effort. Data were not available to compare the effectiveness of establishing vegetation without tillage on compacted tank trails. The compacted surface soil of the tank trails may not have provided a suitable seed germination site without some type of seedbed preparation. A less costly method of tillage should be evaluated to determine if tillage is necessary for the establishment of vegetation on compacted tank trails. Both ground cover and cost data from this study indicate that extensive tillage for seedbed preparation is not necessary or cost-effective.

The high per-hectare cost for hydroseeding (prescriptions 6 and 7) was due, in part, to the lack of a water source on the site and to the cost of transporting water from a river off HTA to the site. Hydroseeded areas were also small and located throughout the site, which probably added to 
TABLE 4 Average Cost per Unit for Labor and Equipment Used during the Rehabilitation of the Range $8 \mathrm{C}$ Site

\begin{tabular}{|c|c|c|c|}
\hline \multirow[b]{2}{*}{ Item } & \multirow[b]{2}{*}{ Unit } & \multicolumn{2}{|c|}{ Cost $^{\dagger}$} \\
\hline & & DM & $\$$ \\
\hline Fertilizing & ha & $379 \ddagger$ & 149 \\
\hline Seeding & ha & $605^{\ddagger}$ & 281 \\
\hline Tillage & ha & $1,000 \ddagger$ & 465 \\
\hline Leveling and ripping & ha & $2,600 \ddagger$ & 1209 \\
\hline Hydroseed (meadow) & ha & $12,284^{\ddagger}$ & 5713 \\
\hline Hydroseed (forest) & ha & $14,292 \ddagger$ & 6647 \\
\hline Grading (terraces and waterways) & $\mathrm{m}^{3}$ & 7.50 & 3.49 \\
\hline Riprap placement (waterbars and check dams) & $\mathrm{m}^{3}$ & 35.00 & 16.28 \\
\hline
\end{tabular}

†2.15 DM $=\$ 1.00$.

\#Rounded to the nearest Deutsche mark and U.S. dollar.

the per-unit-area cost of this revegetation method. Even if water had been available on-site and if a single large area had been hydroseeded, the costs of hydroseeding would have probably been disproportionately higher than those of the other revegetation prescriptions. The lack of on-site water and scattered locations of hydroseeded areas indicate that hydroseeding is generally not a practical method for establishing vegetation on training areas. Hydroseeding may be required on critical areas where other revegetation is not possible (because of steep slopes, for example) and where the vegetation will not be damaged by vehicle traffic.

The cost for grading an individual meter of terrace is relatively low, but the cost of grading the entire terrace system is considerable. In addition, a relatively large area that is disturbed by grading must be fertilized and seeded. Field observations indicate that the terrace system functioned as designed, but the conditions on a training area are somewhat different than those on a cultivated agriculture field. Terraces were effective in controlling erosion immediately after the tillage and seeding operation, but their value decreased as vegetation became established. One year after application of the prescriptions, adequate ground cover had developed to control erosion on most of the slopes above the terraces. In addition, the lack of a suitable outlet for terraces as a result of damage to the waterway may have caused increased erosion in the waterway channels. On the basis of these observations and the cost of the terrace system, it was determined that 
building terraces was not an environmentally or economically effective method to control erosion on the Range 8C site.

The cost of the waterways at Range $8 \mathrm{C}$ was not a major factor in determining their suitability for future use on sites that involve vehicle training. Because waterways were used as roads during the initial year of the study, they were not acceptable erosion control structures at Range $8 \mathrm{C}$. The construction of waterbars across the waterway was determined to be effective for preventing the redevelopmint of gullies on the site. Vehicle traffic had pushed some of the riprap into the bottom of the waterway channel, but a layer of rock had prevented cutting in the waterway channel. The relatively low cost and durability of these structures indicate that riprap could be used to prevent and retard erosion in gullies on training areas.

Observations of the larger waterbars across the old tank trails and the porous check dams confirmed the suitability and durability of riprap structures. These structures had reduced the velocity of runoff and trapped sediments. Several of the structures had been crossed by vehicles, but damage was limited and their effectiveness was not impaired. The larger waterbars across the old tanks trails apparently discouraged the use of some trails, thus preventing the destruction of ground cover and renewed erosion on areas up-slope of the structures. Because riprap structures were relatively inexpensive and durable, they could be effective for erosion control on areas that are subject to vehicle traffic. 


\section{Summary and Conclusions}

Immediately after the implementation of the prescriptions, 27 permanent transects were established to monitor the types and amounts of vegetation in various prescription and reference areas at the site. Ground cover data were collected from each transect by using the point-intercept method during the fall of 1986 and each spring, summer, and fall through April 1990. The relative amount of damage caused by vehicle traffic on each transect was recorded during each monitoring session. The data were assembled into seven categories, and each category was statistically analyzed to compare the types and amounts of cover among prescriptions and collection dates.

Ground cover data collected during the initial growing season indicate that all revegetation prescriptions established or increased the amount of vegetative cover on the site. The data indicated that fertilization and seeding are probably the major factors in establishing new ground cover, while the degree of seedbed preparation is less important in establishing plant cover. Substantial increases in the percent grass cover were observed on all prescription areas; significant increases were observed on areas that were barren before fertilization and seeding. Legumes and other forbs had a lower (and generally slower) rate of establishment, but legume and other forb cover increased throughout the initial growing season. Cereal rye, which was included in the seed mixture to provide quick cover for erosion control, was observed only on newly seeded barren areas. Increases in total vegetative cover were generally proportional to the amount of grass established, and by the fall of the first growing season, $75 \%$ or more vegetative cover was observed on all prescription areas. Grass and total veretative cover remained about the same on the native vegetation reference area during the first giowing season. Data from the natural revegetation reference area showed that natural revegetation did occur, but the rate of revegetation was slow. Grass cover on this reference area increased by about $13 \%$, while total cover increased by less than $45 \%$. The data indicate that the type of ground cover established by the natural revegetation process may not provide effective erosion control.

Range $8 \mathrm{C}$ was reopened for military use one year after implementation of the prescriptions, and the ground cover data collected after that date clearly show that military vehicle traffic destroyed vegetative cover. The types and amounts of vegetative cover that survived on the transects were proportional to the amount and frequency of vehicle traffic on the area. Data collected during the three-year period indicate that grass withstood vehicle traffic better than did legumes and other forbs (because a larger proportion of grass cover survived on trafficked areas). The data also indicate that ground cover can be established on barren areas, and more than $50 \%$ vegetative cover remained on these areas after three years with some vehicle traffic. The results of three years of monitoring indicate that implementation of revegetation prescriptions increas $: \cdot d$ the amount of ground cover at the site, but periodic fertilization and seeding were required to maintain an acceptable level of vegetative cover to control erosion.

A graded terrace system was constructed at the site to reduce erosion rates by shortening slope lengths and lessening overland flows of runoff. A grassed waterway system with riprap waterbars across the waterway channels at selected locations was constructed to control and reduce 
the velocity of runoff and to provide outlets for the graded terraces. Larger riprap waterbars were installed across tank trails at old field boundaries to discourage traffic on the trails, reduce the velocity of runoff down the trails, and trap any sediments eroded from the trails. A series of five porous check dams made of riprap was installed in the main drainage channel at the site. The porous dams were designed to drain after each runoff event, trap sediments, and reduce the velocity of runoff water before it left the site. Field observations were made during each ground cover monitoring session to determine the practicality and durability of these erosion control structures. The results of this study show that grassed waterways and terraces are not practical in training area rehabilitation. The results also indicate that riprap structures are effective and economical structures for erosion control.

Although Range 8C was officially closed to military use for one year after implementation of the prescriptions, some unauthorized use of the site was observed. During the spring 1987 monitoring session, there was evidence that the grassed waterways had been used as roads by several vehicles. The traffic left two tracks down the waterway channel and dan ager developing vegetation. Runoff converged in these tracks, and erosion rills had developed. The riprap waterbars across the waterway channels prevented the development of deep gu:!ies. The use of the waterways as roads also reduced the effectiveness of the terr: $: e$ system because the outiet for the terrace system had been damaged.

The erosion control structures had been designed to withsiand a 25-yeas rainfall event, but in July 1987, a 100-year rainfall event occurred at the site. The above-normal runoff caused additional erosion in the waterway channels, but the waterbas; prevented cutting and gully development. Some of the smaller riprap from the check dams in the main drainage channel was washed downstream, but this damage did not reduce the efiectiveness of the porous check-dams. Other erosion control structures installed at the site withstood this record rainfall without apparent damage.

During the next three years of monitoring (while normal military use of the site for tactical training continued), all of the erosion control structures, with the exception of the grassed waterways, appeared to be functioning as designed. A major trail developed in one of the waterways, but the waterbars continued to prevent cutting and gullies did not develop. Some damage had been sustained by each type of structure during the three years of use, but all structures were still reducing the rate of soil erosion by slowing the velocities of runoff and trapping sediments before the sediments left the site.

On the basis of the ground cover data and the costs of the prescriptions, fertilization and seeding are the mosi economical methods of reestablishing vegetation for erosion control. Cost information indicated that extensive seedbed preparation (including ripping and leveling) increases cost but does not yield an apparent increase in the amount of ground cover established. The cost of hydroseeding indicated that this method of revegetation should only be used on critical areas where other methods cannot be used and where vehicle traffic will not occur in the future. The high cost of terrace construction and seeding, combined with the short-term benefits of this method, indicates that terraces are not cost-erfiective erosion controi structures on training areas. The 
construction of a grassed waterway system on training areas where vehicle traffic occurs is not an effective erosion control method because the waterway channels are often used as roads. The construction of riprap structures to reduce the velocity of runoff, trap sediments, and prevent erosion is both economically and environmentally sound because such structures are relatively inexpensive and durable. 


\section{Recommendations}

The fourth and final objective of the Range $8 \mathrm{C}$ monitoring effort was to recommend improved prescriptions that could be used for rehabilitating tactical training areas in the future. The following recommendations were formulated on the basis of (1) the experience gained during the implementation of the prescriptions and (2) the four-year monitoring effort. These recommendations are intended to be applicable to training areas with soil conditions, climatic conditions, and environmental problems similar to those at Range 8C, but they may not be applicable to individual situations at all tactical training areas.

Prior to the planning of any rehabilitation activities, detailed information is needed on the type of training that is conducted at the site. Detailed interviews with those who regularly use the site will provide information on how to integrate training needs with rehabilitation prescriptions to provide a safe, realistic training habitat that will also conserve natural resources and protect the environment. Rehabilitation efforts will only be successful if those who use the site, in this case the military, can see future benefits from the project.

Detailed site-specific information is also necessary to plan a cost-effective rehabilitation plan. An important requirement is a detailed topographic map of the site and adjacent areas with appropriate contour intervals. With this map, one can determine slope angles and length, natural watercourses, and watershed areas. This map should also be used to record the types and amounts of existing vegetation, the various soil conditions, and the locations of major gullies. If possible, the site should be inspected periodically over one year and during runoff events. The amounts and types of vegetation change from season to season. Observations made during a rainfall event can indicate erosion problems that would not be apparent without runoff. These factors are major influences in the selection of prescriptions to meet environmental and training needs at the site.

Implementation of a prescription should be planned to take full advantage of any seasonal conditions. For example, if seeding is included, the rehabilitation effort should be planned to take full advantage of optimal seasonal temperatures and precipitation. The specifications for prescriptions need not be complicated to be effective, and some flexibility is needed to adjust specifications to unexpected situations encountered during implementation. For this reason, onsite supervision - with the authority to make necessary modifications during implementation may be needed to meet the intended purpose of the rehabilitation effort.

Ground cover data collected at the Range $8 \mathrm{C}$ site indicate that (1) fertilization improved existing vegetation and (2) seeding was necessary to establish cover on areas without existing vegetation. Cost data indicate that one-half or more of the total cost of these prescriptions was for labor and equipment use. Therefore, it is important to apply sufficient and appropriate amounts of fertilizer and seed to avoid a poor response and the need to reapply these materials. The types and amounts of fertilizer and other soil amendments to be applied must be determined by the results of soil analyses. Generally, the broadcast application of fertilizer and seed is preferred because areas around trees and rocks, wet spots, and standing water can be treated. These areas are inaccessible 
to other application methods. Species in the seed mixture must be selected to match local climatic conditions and soil properties found at the site. Seeding rates should be about one and one-half the normal rate to ensure an acceptable stand.

Cereal rye was included in the seed mixture used at the Range $8 \mathrm{C}$ site to provide quick cover for immediate erosion control. Ground cover data indicate that during the initial growing season, the rye did not become as well established as had been expected. Although the rye set seed, it did not reseed and was, generally, not observed in the vegetative cover after the first year. For these reasons, alternative species that can provide quick cover and immediate erosion control (such as annual or perennial ryegrass) should be considered. Seeding rates for quick-cover species should be comparatively low because these aggressive species prevent (or retard) the more desirable species in the seed mixture from becoming established.

Data collected during the Range $8 \mathrm{C}$ monitoring effort indicate that extensive seedbed preparation may not be necessary to establish vegetation on training areas. Cost data confirm that seedbed preparation represents a large proportion of the cost of some revegetation prescriptions. Therefore, additional studies are needed to evaluate less extensive and less costly methods of seedbed preparation.

Field observations indicated that grassed waterways were used as roads on the Range $8 \mathrm{C}$ site. Vehicle traffic destroyed vegetation in the waterway channels and led to renewed erosion. For these reasons, the construction of grassed waterways on training areas is not recommended. Also, the construction of graded terraces on training areas cannot be recommended because a suitable outlet, normally a grassed waterway, cannot be provided. Terraces are also relatively expensive and provide only short-term benefits.

Observations at the Range $8 \mathrm{C}$ site indicate that riprap structures (such as waterbars across the waterway channels and across tank trails at old field boundaries and porous check dams) are both effective and durable. The cost of these structures is relatively low compared with the benefits of slowing runoff and trapping sediments before they leave the site. The use of riprap structures to block gullies and limit access to sensitive areas should be considered in future projects to rehabilitate training areas.

As with most initial research efforts, the Range $8 \mathrm{C}$ project left many questions unanswered regarding the cost-effective rehabilitation of tactical training areas. Additional research is needed to select traffic-resistant plant species for revegetation. Studies are also needed to determine if seedbed preparation is necessary to establish acceptable ground cover for effective erosion control. Nevertheless, this study demonstrated that tactical training areas could be rehabilitated to conserve natural resources and improve the training environment. 


\section{References}

Beasley, R.P., 1972, Erosion and Sediment Pollution Control, Iowa State University Press, Ames, Iowa.

Chambers, J.E., and R.W. Brown, 1983, Methods for Vegetation Sampling and Analysis on Revegetated Mined Land, U.S. Department of Agriculture, Forest Service, Intermountain Forest and Range Experiment Station, General Technical Report INT-151, 57 pp.

Griesbach, E., 1988, Truppenübungsplatz Hohenfels Geschichte einer Landschaft, Flierl-Druck KG, Amberg, Germany.

Hoffman, L., R.E. Ries, and J.E. Gilley, 1983, Relationship of Runoff and Soil Loss to Ground Cover of Native and Reclaimed Grazing Land, Agronomy J., 75(4):599-602.

Lee, C.R., et al., 1985, Restoration of Problem Soil Materials at Corps of Engineering Construction Sites, Instructional Report EL-85-2, Department of the Army Waterways Experiment Station, Vicksburg, Miss.

Meeuwig, R.O., 1970, Infiltration and Soil Erosion as Influenced by Vegetation and Soil in Northern Utah, J. of Range Management, 25:185-188.

Miller, R.G., Jr., 1966, Simultaneous Statistical Inference, McGraw-Hill, New York, N.Y.

Ray, A.A., ed., 1982, SAS User's Guide: Statistics, 1982 Ed., SAS (Statistical Analysis System) Institute Inc., Cary, N.C.

Wischmeier, W.H., and D.D. Smith, 1978, Predicting Rainfall Erosion Losses - A Guide to Conservation Planning, U.S. Department of Agriculture, Agriculture Handbook No. 537.

Zellmer, S.D., et al., 1987, Documentation of the Range $8 C$ Rehabilitation Demonstration Project at Hohenfels Training Area, West Germany, Argonne National Laboratory Report ANL/ESD/TM-26, Argonne, Ill. 

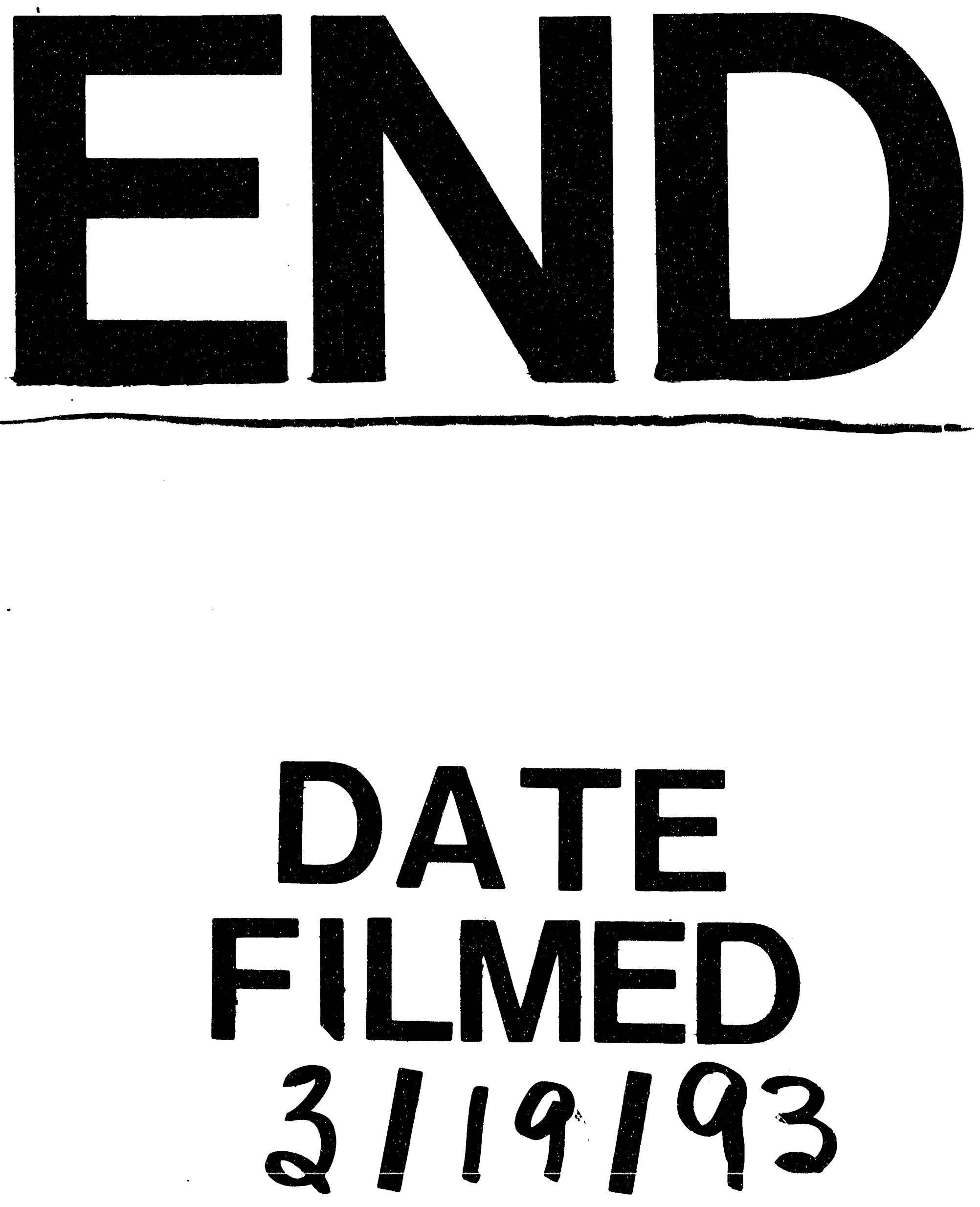
